\title{
Impact of mechanical ventilation and fluid load on pulmonary glycosaminoglycans
}

\author{
Andrea Moriondo ${ }^{a}$, Cristiana Marcozzi ${ }^{a}$, Francesca Bianchin ${ }^{a}$, Marcella Reguzzoni ${ }^{a}$, Paolo Severgnini $^{\mathrm{b}}$, \\ Marina Protasoni ${ }^{a}$, Mario Raspanti ${ }^{a}$, Alberto Passi ${ }^{a}$, Paolo Pelosi ${ }^{c}$, Daniela Negrini ${ }^{a}{ }^{*}$ \\ a Dept. Surgical and Morphological Sciences, University of Insubria, Varese, Italy \\ ${ }^{\mathrm{b}}$ Dept. Environment, Health and Safety, University of Insubria, Varese, Italy \\ ${ }^{c}$ Dept. of Surgical Sciences and Integrated Diagnostics, University of Genoa, Genoa, Italy
}

\section{A R T I C L E I N F O}

\section{Article history:}

Accepted 17 March 2012

\section{Keywords:}

Ventilator-induced lung injury

Positive end-expiratory pressure (PEEP)

Pulmonary interstitium

Lung mechanics

Lung proteoglycans

\begin{abstract}
A B S T R A C T
The combined effect of mechanical ventilation and fluid load on pulmonary glycasaminoglycans (GAGs) was studied in anaesthetized rats ((BW $290 \pm 21.8$ (SE)g) mechanically ventilated for $4 \mathrm{~h}$ : (a) at low $\left(\sim 7.5 \mathrm{ml} \mathrm{kg}^{-1}\right)$ or high $\left(\sim 23 \mathrm{ml} \mathrm{kg}^{-1}\right)$ tidal volume $\left(V_{\mathrm{T}}\right)$ and zero alveolar pressure; (b) at low or high $V_{\mathrm{T}}$ at $5 \mathrm{cmH}_{2} \mathrm{O}$ positive end-expiratory pressure (PEEP); (c) with or without $7 \mathrm{ml} \mathrm{kg}^{-1} \mathrm{~h}^{-1}$ intravenous infusion of Phosphate Buffer Solution (PBS). Compared to spontaneous breathing, GAGs extractability decreased by $52.1 \pm 1.5 \%$ and $42.2 \pm 7.3 \%$ in not-infused lungs mechanically ventilated at low $V_{\mathrm{T}}$ or at high $V_{\mathrm{T}}$ and PEEP, respectively. In contrast, in infused lungs, GAGs extractability increased by $56.1 \pm 4.0 \%$ in spontaneous ventilation and PEEP and up to $81.1 \%$ in all mechanically ventilated lungs, except at low $V_{\mathrm{T}}$ without PEEP. In the absence of an inflammatory process, these results suggest that PEEP was protective at low but not at high $V_{\mathrm{T}}$ when alveolar structures experience exceedingly high stresses. When combined to mechanical ventilation, fluid load might exacerbate edema development and lung injury.
\end{abstract}

(C) 2012 Elsevier B.V. All rights reserved.

\section{Introduction}

The effect of mechanical ventilation on the biochemical composition of lung tissue has been so far poorly investigated. However, the composition and structure of the pulmonary interstitium is crucial for optimal lung efficiency, as interstitial fibrillar components modulate; (a) the interaction between cell surface receptors, growth factors, chemokines and cytokines, influencing tissue repair and remodeling (Johnson et al., 2005); (b) the transmission of local tissue forces to the alveolar and endothelial cells during alveolar expansion with consequences for cellular biophysics, biochemistry and phenotype (Giancotti and Ruoslahti, 1999; Roughley, 2003); (c) the maintenance of tissue compliance and fluid content (Miserocchi et al., 1993). In the lung interstitium, many of these functions are supported by proteoglycans (PGs) (Roberts et al., 1997), a family of multidomain core proteins covalently linked to glycosaminoglycans (GAGs) which have been shown to be involved in stabilizing the lung matrix and maintaining its normal function and fluid content (Miserocchi et al., 1993, 2001; Negrini et al., 1996, 2006).

\footnotetext{
* Corresponding author at: Dept. Surgical and Morphological Sciences, University of Insubria, Via J.H. Dunant 5, 21100 Varese, Italy. Tel.: +39 0332 397104; fax: +390332397119 .

E-mail address: daniela.negrini@uninsubria.it (D. Negrini).
}

Albeit necessary for patient survival, mechanical ventilation may induce the development of ventilator induced lung injury (VILI), implying damage to epithelial (Budinger and Sznajder, 2006) and endothelial (Marini et al., 2003) cells, to peripheral airways (D'Angelo et al., 2002; Jain and Sznajder, 2007) and, last but not least, to the extracellular matrix (Al Jamal and Ludwig, 2001; Parker et al., 1997). Pulmonary GAGs seems to be particularly sensitive to tissue stress, as suggested by the observation that short term ( $4 \mathrm{~h})$ mechanical ventilation with room air is accompanied by a tidal volume $\left(V_{\mathrm{T}}\right)$ dependent fragmentation and washout of GAGs (Moriondo et al., 2007). On the other hand, excessively high tidal volume in mechanical ventilation seems to trigger PG deposition in rats (Al Jamal and Ludwig, 2001). Use of positive end-expiratory pressure (PEEP), by minimizing the stress/strain imposed to the alveolar structures through a more homogenous alveolar expansion, potentially reduces the impact of mechanical ventilation. However, the actual role of PEEP remains unclear. Indeed, indications on the protective role of PEEP come from experimental models of lung injury (dos Santos and Slutsky, 2004), or from healthy lungs ventilated with open chest (D'Angelo et al., 2002, 2004) or at negative end-expiration pressure (D'Angelo et al., 2005), or with intermittent recruitment maneuvers (Duggan and Kavanagh, 2005). It is therefore difficult to infer from these studies which is the selective effect of PEEP in ventilation of normal lungs at different lung volumes. 
An additional factor, often accompanying patient ventilation in the clinical setting, is plasma expansion. It has been shown that, even in spontaneously breathing lungs, increased plasma volume interferes with GAGs/PGs behavior, loosening the intermolecular bonds within the fibrillar matrix and modifying the mechanical behavior of the matrix itself (Miserocchi et al., 1993; Negrini et al., 1996; Passi et al., 1998). In spite of the potentially critical interplay between ventilatory setting and fluid load in the evolution of lung injury in ventilated patients, the effect of low or high lung volume ventilation with and without PEEP and with or without fluid load has never been thoroughly investigated yet. Therefore, in this study we aimed at studying the combined effect of various ventilatory strategies and fluid load in conditions as close as possible to the normal ones, so as to be able to detect the very early phases of development of ventilatory induced lung injury. In particular we hypothesized that: (a) mechanical ventilation "per se" induces a worse damage to pulmonary GAGs as compared to spontaneous breathing; (2) PEEP has a protective effect on changes in pulmonary GAGs during mechanical ventilation, independently of tidal volume; (3) the administration of fluids may further damage pulmonary GAGs in association with mechanical ventilation. To test our hypothesis we exposed healthy anaesthetized rats to various combinations of: (a) spontaneous or mechanical ventilation; (b) low or high $V_{\mathrm{T}}$; (c) absence or presence of PEEP and, (d) normal or increased plasma volume. Lung function, mechanical aspects and morphology were examined in view of the pulmonary tissue GAGs content, aiming at defining the least invasive and most protective ventilatory strategy.

\section{Materials and methods}

All experimental procedures and protocols were approved by the Institutional Animal Care Committee at the University of Insubria, Varese, Italy in accordance with the Health Research Extension Act. Experiments were performed on 78 adult pathogen-free male Wistar rats (Charles River; Laboratories Italy, Calco, LC) (BW $290 \pm 21.8$ (SE) g) anaesthetized with an intraperitoneal injection of a cocktail composed by $75 \mathrm{mg} \mathrm{kg}^{-1}$ of ketamine (Sigma-Aldrich, Milan, Italy) and $0.5 \mathrm{mg} \mathrm{kg}^{-1}$ of medetomidine (Domitor, Pfizer) in saline solution. The adequacy of anesthesia level was assessed on the basis of the disappearance of the noxious reflexes. Additional half-boluses of the same anesthetic cocktail were administered every hour until the end of the experiments, when animals were euthanized via an anesthesia overdose. Once deeply anaesthetized, the rats were turned supine on a heating pad set to maintain the body temperature at $\sim 37^{\circ} \mathrm{C}$. After tracheotomy, a T-shaped cannula inserted into the trachea was connected to a heated Fleish pneumotachograph (model 8420, Hans Rudolph Inc.) equipped with a differential pressure transducer $\left(2 \mathrm{cmH}_{2} \mathrm{O}\right.$; Validyne MP45, Northridge, CA) to continuously monitor airflow $\left(\dot{V}_{E}\right)$. The flow signal was digitized with a National Instruments BNC-2090 analogto-digital board (sampling rate: $100 \mathrm{~Hz}$ ) and integrated by a dedicated LabView software (National Instruments) to obtain respiratory tidal volume $\left(V_{\mathrm{T}}\right)$. Airways pressure $\left(P_{\mathrm{AW}}\right)$ was measured with a physiological pressure transducer (model P23XL; Gould Electronics) connected to the side arm of the tracheal cannula; there was no appreciable shift in the signal or alteration in amplitude up to $20 \mathrm{~Hz}$. All recorded signals were amplified, sampled at $100 \mathrm{~Hz}$ by a 14-bit analog-to-digital converter and stored on a desk computer. Oesophageal pressure (PES) was measured through an oesophageal balloon whose correct positioning was assessed by the Baydur test (Baydur et al., 1982). Saline filled plastic catheters (PE50) were inserted into the carotid artery and the jugular vein to continuously monitor systemic arterial and central venous pressures. In rats exposed to extracellular fluid load, an additional catheter was inserted into a femoral vein to be connected to a continuous infusion pump (KDS 100L, KD Scientific, Holliston, MA, USA).

\subsection{Experimental protocols}

A first set of animals (not-infused, NI; $n=28,4$ rats per group) were randomly assigned to the following experimental groups: (a) untreated controls, suppressed through an anesthesia overdose without being exposed to any experimental instrumentation or treatment (group $\mathrm{C}_{0}, n=4$ ); (b) anaesthetized and instrumented rats suppressed after $4 \mathrm{~h}$ of spontaneous breathing (SB) with room air at $0 \mathrm{cmH}_{2} \mathrm{O}$ end-expiratory pressure (ZEEP) (group $\mathrm{C}_{4 \mathrm{~h}} ; n=4$ ); (c) anaesthetized and instrumented rats suppressed after $4 \mathrm{~h}$ of SB with room air at $5 \mathrm{cmH}_{2} \mathrm{O}$ PEEP (group $\mathrm{C}_{4 \mathrm{~h}-\mathrm{P}} ; n=4$ ); (d) anaesthetized and instrumented rats which, after $10 \mathrm{~min}$ baseline $\mathrm{SB}$, were mechanically ventilated (ventilator model SPIRA, Harvard Instruments) for $4 \mathrm{~h}$ with room air at ZEEP (group $\mathrm{MV}_{\mathrm{L}} ; n=4$ ) or PEEP-5 (group $\mathrm{MV}_{\mathrm{L}-\mathrm{P}} ; n=4$ ) at the same $V_{\mathrm{T}}$, respiratory rate and therefore $\dot{V}_{E}$ as in baseline SB. Prior to the beginning of mechanical ventilation rats were paralyzed with a single bolus of $0.3 \mathrm{ml}$ of pancuronium bromide (Sigma-Aldrich, Milan, Italy) solution $(2 \mathrm{mg} / \mathrm{ml}$ in saline) delivered in the femoral catheter; (e) anaesthetized and instrumented rats which, after $10 \mathrm{~min}$ baseline spontaneous breathing, were mechanically ventilated for $4 \mathrm{~h}$ with room air at ZEEP (group $\mathrm{MV}_{\mathrm{H}} ; n=4$ ) or PEEP-5 (group $\mathrm{MV}_{\mathrm{H}} ; n=4$ ) maintaining the baseline $\dot{V}_{E}$ through a 3 fold higher $V_{\mathrm{T}}$ compared to $\mathrm{SB}$, and a correspondingly decreased ( $1 / 3$ compared to $S B$ ) respiratory rate.

A second set of animals (infused, I, $n=24$ ) was used to verify whether an increased tissue hydration might have an additional impact, either protective or injurious, on lung parenchyma exposed to different ventilatory strategies. Therefore, rats ventilated as in previous points (b) through (e) in addition received an intravenous infusion of PBS at a constant rate of $7 \mathrm{ml} \mathrm{kg}^{-1} \mathrm{~h}^{-1}$ maintained for $4 \mathrm{~h}$.

\subsection{Respiratory mechanics}

In not-infused and infused $\mathrm{MV}_{\mathrm{L}}, \mathrm{MV}_{\mathrm{L}-\mathrm{P}}, \mathrm{MV}_{\mathrm{H}}$ and $\mathrm{MV}_{\mathrm{H}-\mathrm{P}}$ rats, the dynamic pressure-volume (PV) curves of the respiratory system were computed off line at the beginning and at the end of the mechanical ventilation. For each rat, the dynamic PV plots of ten subsequent respiratory cycles were averaged. The dynamic compliance of the respiratory system at the beginning $\left(C_{R S, d y n-0}\right)$ and at the end $\left(C_{R S, d y n-4 h}\right)$ of the period of mechanical ventilation was calculated as the ratio between the measured $V_{\mathrm{T}}$ and the peak airway pressure $\left(P_{\mathrm{PEAK}-\mathrm{AW}}\right)$ at end-inspiration, i.e. $C_{\mathrm{RS} \text {,dyn- } 0}=V_{\mathrm{T}} / P_{\text {PEAK-AW- } 0}$ and $\mathrm{C}_{\mathrm{RS} \text {,dyn- } 4 \mathrm{~h}}=V_{\mathrm{T}} / P_{\mathrm{PEAK}-\mathrm{AW}-4 \mathrm{~h}}$, respectively. The dynamic end-inspiratory transpulmonary pressure $\left(\Delta P_{\mathrm{L}, \mathrm{dyn}}\right)$ at baseline and at the end of the experiment was calculated as: $\Delta P_{\mathrm{L}, \mathrm{dyn}}=P_{\text {PEAK-AW }}-\left(P_{\text {PEAK-ES }}-P_{\text {EXP-ES }}\right)$ where $P_{\text {PEAK-ES }}$ and $P_{\text {EXP-ES }}$ are the peak inspiratory and end-expiratory esophageal pressure, respectively. At the end of the experiment, after sampling arterial blood for gas and serum analysis, the static pressure-volume (PV) curves of the respiratory system, of the lung and of the chest wall were obtained in all groups except $C_{0}$. After connecting the tracheal cannula to a $20 \mathrm{ml}$ syringe, the respiratory system was passively inflated and deflated three times up to a volume of $12 \mathrm{ml}$ above end-expiratory volume, while simultaneously measuring $P_{\mathrm{ES}}$ and $P_{\mathrm{AW}}$. The static PV curve of the lung was obtained by plotting the attained volume as a function of transpulmonary pressure $\left(P_{\mathrm{L}}\right)$, computed offline as $P_{\mathrm{L}}=P_{\mathrm{AW}}-P_{\mathrm{ES}}$. The final static lung compliance $\left(\mathrm{C}_{\mathrm{L}, \mathrm{stat}-4 \mathrm{~h}-\mathrm{l}}\right)$ was calculated as the slope of the relaxation $\mathrm{PV}$ curve at a volume corresponding to $8 \mathrm{ml}$ above endexpiratory volume $\left(\approx 70 \%\right.$ of maximum volume), and $C_{\mathrm{L}, \mathrm{stat}-4 \mathrm{~h}-\mathrm{h}}$, as the slope of the relaxation PV curve in the $8-12 \mathrm{ml}$ range above end-expiratory volume. 
At the end of the static respiratory maneuvers the animals were suppressed with an anesthesia overdose. The lungs were excised from the chest, rinsed in saline solution and larger bronchi were removed from the parenchyma. The latter was then divided into two roughly equal parts: to avoid dehydration one part was immediately weighed to measure the wet tissue weight (W); the specimen were then dried at $70^{\circ} \mathrm{C}$ in a speed vacuum apparatus for $24 \mathrm{~h}$ and weighted again to obtain the dry tissue weight (D). The wet weight to dry weight (W/D) ratio was then calculated and used as a general index of extracellular extravascular lung water content. The other part of the excised lung was cut into smaller pieces and frozen in liquid nitrogen for subsequent biochemical analysis.

\subsection{Biochemical analysis}

The biochemical analysis consisted in the isolation, purification and characterization of glycosaminoglycan (GAG) chains and in the detection of matrix metalloproteinase-2 and 9 MMP-2, MMP-9 and interleuklin-6 (IL-6) from lung extracts.

\subsubsection{GAGs isolation and analysis}

The lyophilized lung samples were extracted with increasing concentration of guanidinium hydrochloride $(\mathrm{GuHCl}), 0.4 \mathrm{M}$ followed by $4 \mathrm{M}$ in $50 \mathrm{mM}$ sodium acetate buffer, $\mathrm{pH}$ 5.6, containing protease inhibitors (Complete Mini EDTA-free tablets, Roche) at $4{ }^{\circ} \mathrm{C}$ for $48 \mathrm{~h}$ (Miserocchi et al., 2001). Distinction between CS-GAGs, extracted from large PGs typical of the solid matrix structures, and HS-GAGs, extracted from PGs preferentially localized in the basal membrane of the endothelial and epithelial membranes, was performed by selective enzymatic digestion using respectively $100 \mathrm{mU} / \mathrm{ml}$ of Chondroitinase ABC (E.C. 4.2.2.4) and a mix of Heparinases I, II, III (E.C.: I 4.2.2.7, II no number, III 4.2.2.8). The product of extraction was then analyzed with the hydroxydiphenyl method (Blumenkrantz and Asboe-Hansen, 1973) as modified by van den Hoogen (van den Hoogen et al., 1998) who adjusted it for a 96 well microtitre plate. This modification is particularly useful for analyzing a large number of samples. Briefly, to each well of the plate was added $40 \mu \mathrm{l}$ of the extraction solution and $200 \mu \mathrm{l}$ of concentrated $\mathrm{H}_{2} \mathrm{SO}_{4}$. The plate was then incubated at $80^{\circ} \mathrm{C}$ for $60 \mathrm{~min}$. After cooling the absorbance was read in a microtitre plate spectrophotometer at $540 \mathrm{~nm}$.

Subsequently, $40 \mu \mathrm{l}$ of m-hydroxydiphenyl reagent $(100 \mu \mathrm{l}$ of $100 \mathrm{mg} / \mathrm{ml}$ mhydroxydiphenyl in dimethyl sulphoxide, mixed with $4.9 \mathrm{ml} 80 \%$ sulfuric acid) were added, and after $15-30 \mathrm{~min}$ the absorbance at $540 \mathrm{~nm}$ was read again. Quantification of uronic acid was made against a glucuronic acid standard. The uronic acid content was expressed as $\mu \mathrm{g}$ of glucuronic acid mg- 1 of dry tissue. Derivatization of GAG $\Delta$-disaccharides was done as described by Calabro et al. (2000), using the dried sampled derived from $100 \mu \mathrm{l}$ of the enzymatic digestion. A $40 \mu \mathrm{l}$ volume of $12.5 \mathrm{mM}$ of 2-aminoaciridone (AMAC) solution in glacial acetic acid/DMSO $(3: 17, v / v)$ was added and samples incubated for $10-15 \mathrm{~min}$ at room temperature. A $40 \mu \mathrm{l}$ volume of a freshly prepared solution of $1.25 \mathrm{M} \mathrm{NaBH}{ }_{3} \mathrm{CN}$ in water was added to each sample followed by an overnight incubation at $37^{\circ} \mathrm{C}$. Separation and analysis of AMAC-derivatives of $\Delta$-disaccharides were done as described by Karousou et al. (2004) with a Jasco-Borwin chromatograph system with a fluorophore detector (Jasco FP-920, $\lambda_{\text {ex }}=442 \mathrm{~nm}$ and $\lambda_{\mathrm{em}}=520 \mathrm{~nm}$ ). Chromatography was carried out using a reversed phase column $(\mathrm{C}-18,4.6 \mathrm{~mm} \times 150 \mathrm{~mm}$, Bischoff $)$ at room temperature, equilibrated with $0.1 \mathrm{M}$ ammonium acetate buffer, $\mathrm{pH} 7.0$, filtered through a $0.22 \mu \mathrm{m}$ membrane filter. A gradient elution was done using a binary solvent system composed of $0.1 \mathrm{M}$ ammonium acetate buffer, $\mathrm{pH} 7.0$ (eluent $\mathrm{A}$ ), and acetonitrile (eluent $\mathrm{B}$ ). The flow rate was $1 \mathrm{ml} / \mathrm{min}$, and the following program was used: prerun of column with $100 \%$ eluent $A$ for 20 min, isocratic elution with
$100 \%$ eluent A for $5 \mathrm{~min}$, gradient elution to $30 \%$ eluent B for $30 \mathrm{~min}$ and from $30 \%$ to $50 \%$ for $5 \mathrm{~min}$. Sample peaks were identified and quantified comparing the fluorescence spectra with standard $\Delta$ disaccharides, using Jasco-Borwin software.

\subsubsection{MMPs purification and detection}

For the detection of MMP-2 and MMP-9 activities (Mazzieri et al., 1997), cryopreserved lung specimens were homogenized in PBS and MMPs were purified with gelatin-Sepharose resin (Amersham Bioscences) $(4: 1, \mathrm{v} / \mathrm{v})$ for $2 \mathrm{~h}$ at $4{ }^{\circ} \mathrm{C}$. After centrifuging the gelatin Sepharose, recovered as a pellet, was washed 4 times with a buffer $10 \mathrm{mM}$ Tris- $\mathrm{HCl}, 200 \mathrm{mM} \mathrm{NaCl}, 20 \mathrm{mM}$ EDTA, $\mathrm{pH} 7.5$ and then eluted with 4 successive aliquots of the same buffer adjusted to $10 \%$ dimethylsulphoxide (v/v) (Mazzieri et al., 1997). Kinetic studies were carried out at $25^{\circ} \mathrm{C}$ using a fluorimetric assay with a quenced fluorescent substrate (Murphy et al., 1994). Progelatinases MMP-2 and MMP-9 were activated by incubation with p-aminophenylmercuric acetate (APMA $1 \mathrm{mM}$, Sigma) in TCNB buffer (50 mM Tris, $10 \mathrm{mM} \mathrm{CaCl} 2,150 \mathrm{mM} \mathrm{NaCl}, 0.005 \%$ Brij 35, $\mathrm{pH} \mathrm{7.5)}$ at $37^{\circ} \mathrm{C}$ for $2 \mathrm{~h}$. Enzyme concentrations were determined using a standard curve of recombinant rat MMP-2 (R\&D Systems) activated by incubation with APMA ( $1 \mathrm{mM}$, Sigma) $(40 \mu \mathrm{g} / \mathrm{ml})$ and measuring its ability to cleave two different fluorescent peptide substrates (MMP-2 and MMP-2/MMP-9 substrate fluorogenic, Calbiochem) using excitation and emission wavelengths of $325 \mathrm{~nm}$ and $393 \mathrm{~nm}$, respectively for MMP-2, and $280 \mathrm{~nm}$ and $360 \mathrm{~nm}$, respectively for MMP-2/MMP-9. To detect fluorescence, a luminescence spectrometer (LS 50 B, Perkin Elmer) was used. The results were expressed by ng MMP-2/ $\mu$ g protein (protein quantification by Bradford assay (Bradford, 1976). Inactive MMP-2 and MMP-9 were quantified as the difference between activated and not activated MMP and confirmed by zymography using a gel embedded with gelatine as substrate.

\subsubsection{ELISA test for cytokines}

The biotrak rat Interleukin-1 beta (IL-1 $\beta$ ), Interleukin-6 (IL-6) and Tumor Necrosis Factor alfa (TNF- $\alpha$ ) ELISA systems (GE Healthcare) have been used following the manufacturer's protocol.

\subsection{Morphological analysis}

In order to evaluate the impact of the ventilatory strategies on the lung tissue from the morphological standpoint, 26 additional rats were used. These animals ( $n=2$ per group) were randomly divided into 13 groups and were exposed to exactly the same surgical preparation and ventilatory procedures previously described for the NI and I rats. At the end of the experimental protocol, the rats were suppressed and the lung was fixed by intracheal instillation with $4 \%$ Karnovsky's solution, at a transpulmonary pressure of $20 \mathrm{cmH}_{2} \mathrm{O}$ (Fehrenbach and Ochs, 1998). The specimens were kept into the fixative solution for $6 \mathrm{~h}$ and then were washed in $0.1 \mathrm{M}$ cacodylate buffer. The samples were postfixed in $1 \% \mathrm{OsO}_{4}$ for $1 \mathrm{~h}$, washed in $0.1 \mathrm{M}$ cacodylate buffer, dehydrated in ascending ethanol and propylenoxyde, and then embedded in epon 812 mixture. The embedded specimens were cut with a RMC MTX ultramicrotome (Boeckeler Instruments Inc., Tucson, AZ, USA) and the obtained semithin section were stained with Toluidin blue and observed with a light microscope (Nikon Eclipse E600). A total of 100,543 alveolar septa (up to 1390 per rat) and 974 alveolar corners (up to 147 per rat) were observed and analyzed from all lung areas.

Quantitative morphological analysis has been performed using an appropriate software for image acquisition and analysis (Simple PCI-Hamamatsu). On each acquired image the following parameters were measured: (a) inter-alveolar septa thickness, (b) alveolar radius; (c) alveolar cross sectional area and (d) area of the peripheral tissue region at alveoli confluence (corner region), 

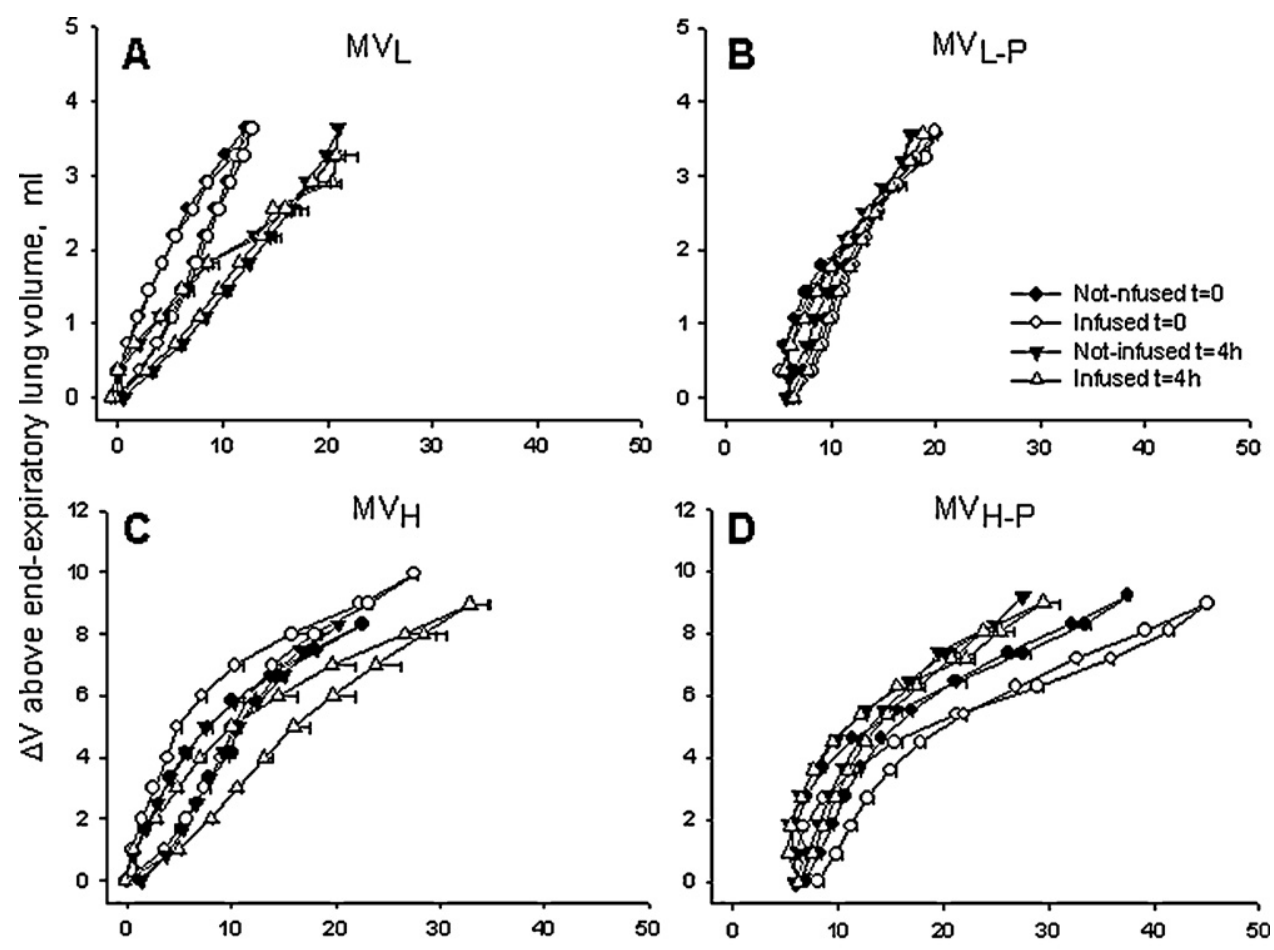

Airways pressure, $\mathrm{CmH}_{2} \mathrm{O}$

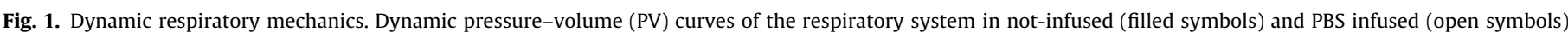

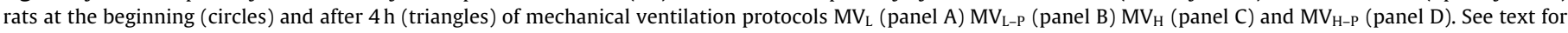
explanation. Bars represent mean $\pm \mathrm{SE}$.

obtained as the surface of the circle inscribed within the corner region.

\subsection{Statistical analysis}

Data are reported as mean $\pm \mathrm{SE}$. Comparison between values from different groups was performed by one-way ANOVA using pairwise multiple comparison procedures (Holm-Sidak method). Comparison between data obtained in the same animals at different times was performed by paired $t$-test. Differences between mean values were considered significant for $p<0.05$.

\section{Results}

In NI rats, mean arterial pressure (MAP) and heart rate (HR) were $112 \pm 2.3 \mathrm{mmHg}$ and $227 \pm 6.7$ cycles $/ \mathrm{min}$ and $108 \pm 11.2 \mathrm{mmHg}$ and $239 \pm 11.3$ cycles/min at the beginning and at the end of the experiment, respectively. In I-rats, MAP and HR were

Table 1

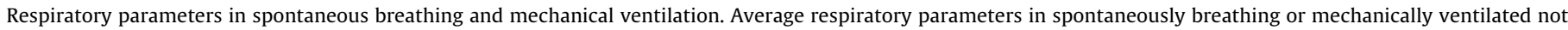

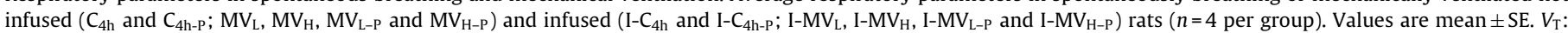

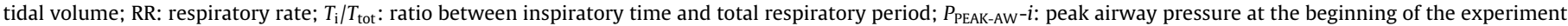
$\left(i\right.$, initial); $P_{\text {PEAK-AW }}-f$ : peak airway pressure at the end of experiment $(f$, final).

\begin{tabular}{|c|c|c|c|c|c|c|}
\hline \multirow[t]{2}{*}{ Not infused } & \multicolumn{2}{|c|}{ Spontaneous breathing } & \multicolumn{4}{|c|}{ Mechanical ventilation } \\
\hline & $\mathrm{C}_{4 \mathrm{~h}}$ & $\mathrm{C}_{4 \mathrm{~h}-\mathrm{P}}$ & $\mathrm{MV}_{\mathrm{L}}$ & $\mathrm{MV}_{\mathrm{H}}$ & $\mathrm{MV}_{\mathrm{L}-\mathrm{P}}$ & $\mathrm{MV}_{\mathrm{H}-\mathrm{P}}$ \\
\hline$V_{\mathrm{T}}, \mathrm{ml}$ & $2.2 \pm 0.2$ & $1.3 \pm 0.2$ & $2.9 \pm 0.3$ & $7.5 \pm 0.6$ & $2.8 \pm 0.2$ & $8 \pm 0.5$ \\
\hline RR, breath/min & $46.7 \pm 1.3$ & $24.6 \pm 1.2^{*}$ & $33.7 \pm 1.2$ & $12.7 \pm 1.4$ & $41 \pm 9.6$ & $13.3 \pm 2.0$ \\
\hline$\dot{V}_{E}, \mathrm{ml} / \mathrm{min}$ & $100.7 \pm 4.7$ & $48.4 \pm 4.9^{*}$ & $86.1 \pm 4.6$ & $93.7 \pm 10.1$ & $110.5 \pm 15.8$ & $105.1 \pm 12.2$ \\
\hline$P_{\text {PEAK-AW }}-i, \mathrm{cmH}_{2} \mathrm{O}$ & & $5 \pm 0.5$ & $12.4 \pm 0.9$ & $23.4 \pm 0.8^{*}$ & $20.2 \pm 0.7^{*}$ & $39.2 \pm 2.1^{*}, \dagger$ \\
\hline$P_{\text {PEAK-AW }}-f, \mathrm{cmH}_{2} \mathrm{O}$ & & $5 \pm 0.5$ & $16.2 \pm 0.7^{\ddagger}$ & $22.5 \pm 1.2$ & $18.8 \pm 0.7$ & $32.8 \pm 1.4^{\ddagger}$ \\
\hline \multirow[t]{2}{*}{ Infused } & \multicolumn{2}{|c|}{ Spontaneous breathing } & \multicolumn{4}{|c|}{ Mechanical ventilation } \\
\hline & $\mathrm{I}-\mathrm{C}_{4 \mathrm{~h}}$ & $\mathrm{I}-\mathrm{C}_{4 \mathrm{~h}-\mathrm{P}}$ & $\mathrm{I}-\mathrm{MV}_{\mathrm{L}}$ & $\mathrm{I}-\mathrm{MV}_{\mathrm{H}}$ & I-MV & $\mathrm{I}-\mathrm{MV}_{\mathrm{H}-\mathrm{P}}$ \\
\hline$V_{\mathrm{T}}, \mathrm{ml}$ & $2.7 \pm 0.2$ & $2.8 \pm 0.05$ & $2.7 \pm 0.3$ & $7.9 \pm 0.7$ & $2.9 \pm 0.05$ & $8.5 \pm 0.4$ \\
\hline $\mathrm{RR}$, breath/min & $46 \pm 8.2$ & $33.5 \pm 2.2$ & $45 \pm 6.7$ & $13.2 \pm 2.2$ & $43.5 \pm 0.5$ & $13 \pm 1.7$ \\
\hline$\dot{V}_{E}, \mathrm{ml} / \mathrm{min}$ & $122.2 \pm 23.1$ & $95.8 \pm 8.2$ & $118.2 \pm 11.5$ & $107.7 \pm 24.9$ & $126.2 \pm 3.5$ & $104.4 \pm 14.7$ \\
\hline$P_{\text {PEAK-AW }}-i, \mathrm{cmH}_{2} \mathrm{O}$ & $0 \pm 0.5$ & $5 \pm 0.5$ & $13.2 \pm 1.8$ & $28.6 \pm 1.6^{*}, \S$ & $20.2 \pm 0.3^{*}$ & $46.7 \pm 3.3^{*}$ \\
\hline$P_{\text {PEAK-AW }}-f, \mathrm{cmH}_{2} \mathrm{O}$ & $0 \pm 0.5$ & $5 \pm 0.5$ & $16.7 \pm 1.0$ & $31.1 \pm 3.0^{\S}$ & $19.7 \pm 0.2$ & $40.2 \pm 5.2$ \\
\hline
\end{tabular}

Significantly different $(p<0.05)$ from $\mathrm{C}_{4 \mathrm{~h}}$ or $\mathrm{MV}_{\mathrm{L}}$.

† Significantly different $(p<0.05)$ from $\mathrm{MV}_{\mathrm{H}}$.

¥ Significantly different $(p<0.05)$ from corresponding baseline value.

$\S$ Significantly different $(p<0.05)$ from corresponding value in not-infused group. 

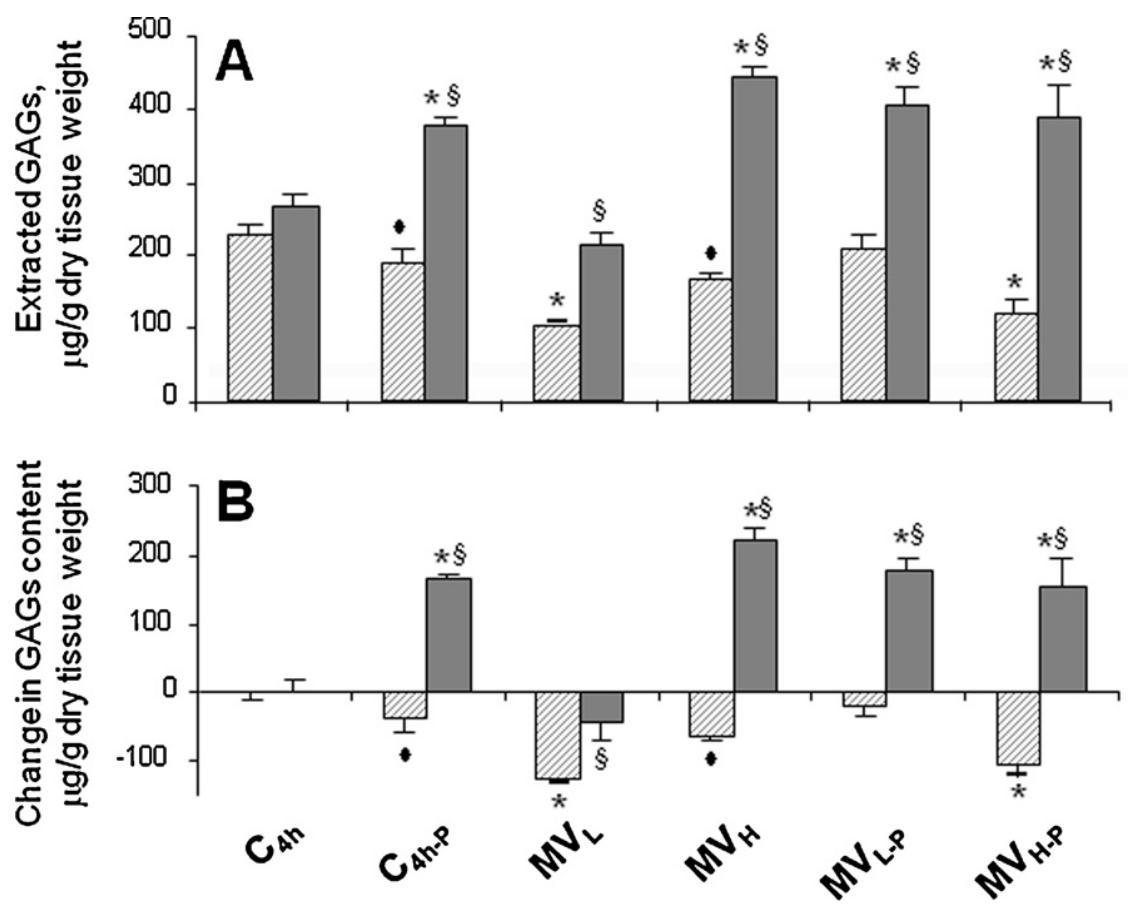

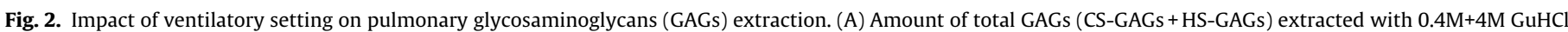

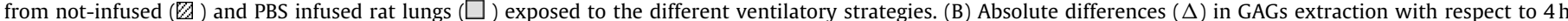

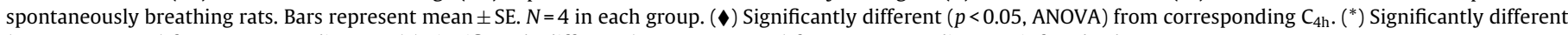
$\left(p<0.01\right.$, ANOVA) from corresponding $C_{4 h}$. $(\S)$ Significantly different $(p<0.01$, ANOVA) from corresponding not-infused value.

$117 \pm 3.3 \mathrm{mmHg}$ and $213 \pm 13.5$ cycles/min at the beginning and, similarly to NI-infused, remained essentially unaltered till the end. Based on the average $V_{\mathrm{T}}(2.2 \pm 0.2 \mathrm{ml})$ in the spontaneously breathing $C_{4 h}$ group (Table 1), the $V_{\mathrm{T}}$ values were set at $7.5 \mathrm{ml} \mathrm{kg}^{-1}$ for $\mathrm{MV}_{\mathrm{L}}$ and $\mathrm{MV}_{\mathrm{L}-\mathrm{P}}$ groups and $23 \mathrm{ml} \mathrm{kg}^{-1}$ for $\mathrm{MV}_{\mathrm{H}}$ and $\mathrm{MV}_{\mathrm{H}-\mathrm{P}}$ groups, while the corresponding $\dot{V}_{E}$ was kept essentially constant. In $\mathrm{C}_{4 \mathrm{~h}-\mathrm{P}}$ respiratory rate and airflow were significantly reduced with respect to $\mathrm{C}_{4 \mathrm{~h}}$, a difference not observed in infused rats. $P_{\text {PEAK-AW }}$ significantly increased at high $V_{\mathrm{T}}$ and/or with PEEP, being highest in $\mathrm{MV}_{\mathrm{H}-\mathrm{P} \text {. }}$. PBS infusion did not significantly affect the respiratory parameters (Table 1).

\subsection{Respiratory mechanics}

Fig. 1A-D presents the dynamic PV curves of the respiratory system in NI- (filled symbols) and I- (open symbols) $\mathrm{MV}_{\mathrm{L}}, \mathrm{MV}_{\mathrm{L}-\mathrm{P}}$, $\mathrm{MV}_{\mathrm{H}}$ and $\mathrm{MV}_{\mathrm{H}-\mathrm{P}}$ groups at the beginning (circles) and at $4 \mathrm{~h}$ (triangles) mechanical ventilation. In both NI- and I-MV $\mathrm{M}_{\mathrm{L}}$ (Fig. $1 \mathrm{~A}$ ) the dynamic PV curves were shifted to the right at $4 \mathrm{~h}$ compared to baseline, as also witnessed by the comparison of the corresponding dynamic compliances $\left(C_{R S \text {,dyn- } 0}\right.$ and $C_{R S \text {,dyn- } 4 h}$, Table 2$)$. This modification was also observed in I-MV $\mathrm{H}_{\mathrm{H}}$, but not in I-MV $\mathrm{MV}_{\mathrm{L}-\mathrm{P}}$ and I-MV $\mathrm{H}-\mathrm{P}$. On the contrary, in NI-MV $\mathrm{V}_{\mathrm{H}-\mathrm{P}}, \mathrm{C}_{\mathrm{RS} \text {,dyn-4h }}$ tended to increase com-

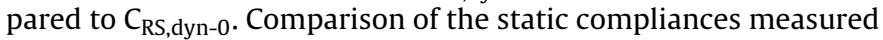
on the static PV curves (not shown) in the volume range $0-8 \mathrm{ml}$ $\left(\mathrm{C}_{\mathrm{L}, \text { stat-4h-l}}\right)$ and 8-12 $\mathrm{ml}\left(\mathrm{C}_{\mathrm{L}, \text { stat-4h- } h}\right)$ above end-expiratory lung volume, respectively, indicates that both in NI and I groups, shifting from spontaneous breathing $\left(\mathrm{C}_{4 h}\right)$ to $\mathrm{MV}_{\mathrm{L}}$ did not affect the static lung parameters (Table 2). In NI-groups, PEEP elicited a variable response, being accompanied by: (a) a significantly reduction of $\mathrm{C}_{\mathrm{L}, \text { stat-4h-l}}$ in $\mathrm{C}_{4 \mathrm{~h}-\mathrm{P}}$ compared to $\mathrm{C}_{4 \mathrm{~h}}$; (b) no appreciable effect in $\mathrm{MV}_{\mathrm{L}-\mathrm{P}}$ and (c) a significant increase of $\mathrm{C}_{\mathrm{L}, \text { stat- } 4 \mathrm{~h}-h}$ in $\mathrm{MV}_{\mathrm{H}-\mathrm{P}}$ in face of a normal value in $\mathrm{MV}_{\mathrm{H}}$. Thus, in mechanical ventilation appreciable changes of the static PV curves were observed only at high $V_{\mathrm{T}}$ and PEEP. PBS infusion had no effect per se on lung mechanics, as indicated by the similar $\mathrm{C}_{\mathrm{L} \text { stat }}$ values in spontaneously breathing $\mathrm{C}_{4 \mathrm{~h}}$ and $\mathrm{I}-\mathrm{C}_{4 \mathrm{~h}}$ lungs. When PBS infusion was accompanied by mechanical ventilation, $\mathrm{C}_{\mathrm{L}, \text { stat }}$ was unchanged at low volume (I$M V_{L}$ ) with respect to $C_{4 h}$, but decreased in $I-M V_{H}$, revealing a modification of the mechanical properties of the lung tissue at high volume and no-PEEP.

\subsection{Gas-analysis}

In NI-rats, mechanical ventilation at low $V_{\mathrm{T}}$ without PEEP $\left(\mathrm{MV}_{\mathrm{L}}\right)$, decreased $\mathrm{pH}_{\mathrm{a}}$ and $\mathrm{P}_{\mathrm{a}} \mathrm{O}_{2}$ and increased $\mathrm{P}_{\mathrm{a}} \mathrm{CO}_{2}$ compared to $\mathrm{C}_{4 h}$ (Table 3). Addition of PEEP $\left(\mathrm{MV}_{\mathrm{L}-\mathrm{P}}\right)$ improved $\mathrm{P}_{\mathrm{a}} \mathrm{O}_{2}$, but not $\mathrm{pH}_{\mathrm{a}}$ and $\mathrm{P}_{\mathrm{a}} \mathrm{CO}_{2}$. With high $V_{\mathrm{T}}\left(\mathrm{MV}_{\mathrm{H}}\right)$ gas-exchange was not modified compared to $\mathrm{C}_{4 \mathrm{~h}}$ while oxygenation further improved with PEEP $\left(\mathrm{MV}_{\mathrm{H}-\mathrm{P}}\right)$. In spontaneously breathing I-rats (I-C $\mathrm{C}_{4 \mathrm{~h}}$ and I- $\left.\mathrm{C}_{4 \mathrm{~h}-\mathrm{P}}\right)$ gasexchange was similar to corresponding NI-groups. Instead, $\mathrm{pH}_{\mathrm{a}}$ decreased in $\mathrm{I}-\mathrm{MV}_{\mathrm{L}}, \mathrm{I}-\mathrm{MV}_{\mathrm{H}}$ and $\mathrm{I}-\mathrm{MV}_{\mathrm{L}-\mathrm{P}}$ compared to NI groups, while $\mathrm{P}_{\mathrm{a}} \mathrm{CO}_{2}$ was not significantly affected. In I-rats the most unfavorable ventilation was MV at low $V_{\mathrm{T}}$ and no PEEP $\left(\mathrm{I}-\mathrm{MV} \mathrm{V}_{\mathrm{L}}\right)$, where hypoxia was worsened with respect to NI-MV $\mathrm{L}_{\mathrm{L}}$. Blood hematocrit was $45.0 \pm 0.37 \%$ at baseline and dropped to $34.4 \pm 1.1$ after $4 \mathrm{~h}$ of $8.3 \pm 0.3 \mathrm{ml}$ of PBS infusion in I-rats. In both NI- and I-rats, the lung wet weight to dry weight ratio (W/D) ratio (Table 4) was significantly increased, compared to $\mathrm{C}_{0}$, only after $4 \mathrm{~h}$ of exposure to high

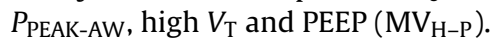

\subsection{Biochemical analysis}

The amount of total (CS- plus HS-) GAGs, extracted with $0.4 \mathrm{M}$ plus $4 \mathrm{M} \mathrm{GuHCl}$ is presented in Fig. 2A for NI- (dashed bars) and I-lungs (dark bars). As evident from Fig. 2B, showing data of Fig. 2A expressed as change with respect to $C_{4 h}$, there was a net difference in GAG extraction in NI-compared to I-lungs. With the exception of $\mathrm{MV}_{\mathrm{L}-\mathrm{P}}$, total GAGs extraction decreased in all NI-lungs, including spontaneously breathing $\mathrm{C}_{4 \mathrm{~h}-\mathrm{P}}$, the largest drop being observed 
Table 2

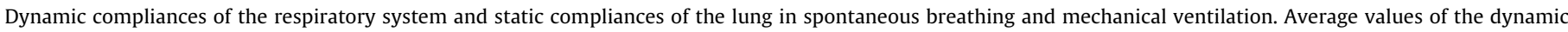

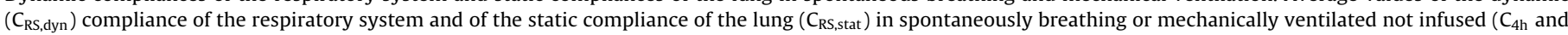

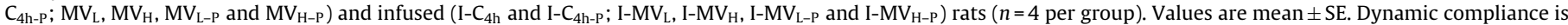

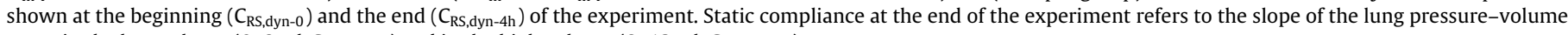
curve in the low volume $\left(0-8 \mathrm{ml}, \mathrm{C}_{\mathrm{L}, \text { stat- }-4 \mathrm{~h}-l}\right)$ and in the high volume $\left(8-12 \mathrm{ml}, \mathrm{C}_{\mathrm{L}, \text { stat }-4 \mathrm{~h}-h}\right)$ range.

\begin{tabular}{|c|c|c|c|c|c|c|}
\hline \multirow[t]{2}{*}{ Not infused } & \multicolumn{2}{|c|}{ Spontaneous breathing } & \multicolumn{4}{|c|}{ Mechanical ventilation } \\
\hline & $\mathrm{C}_{4 \mathrm{~h}}$ & $\mathrm{C}_{4 \mathrm{~h}-\mathrm{P}}$ & $\mathrm{MV}_{\mathrm{L}}$ & $\mathrm{MV}_{\mathrm{H}}$ & $\mathrm{MV}_{\mathrm{L}-\mathrm{P}}$ & $\mathrm{MV}_{\mathrm{H}-\mathrm{P}}$ \\
\hline $\mathrm{C}_{\mathrm{RS}, \mathrm{dyn}-0}, \mathrm{ml} / \mathrm{cmH}_{2} \mathrm{O}$ & - & - & $0.29 \pm 0.01$ & $0.38 \pm 0.03$ & $0.23 \pm 0.01$ & $0.27 \pm 0.01$ \\
\hline $\mathrm{C}_{\mathrm{RS}, \text { dyn- } 4 \mathrm{~h}}, \mathrm{ml} / \mathrm{cmH}_{2} \mathrm{O}$ & - & - & $0.20 \pm 0.01^{*}$ & $0.38 \pm 0.02$ & $0.24 \pm 0.01$ & $0.33 \pm 0.01^{*}$ \\
\hline $\mathrm{C}_{\mathrm{L}, \mathrm{stat}-4 \mathrm{~h}-\mathrm{l}}, \mathrm{ml} / \mathrm{cmH}_{2} \mathrm{O}$ & $0.92 \pm 0.02$ & $0.69 \pm 0.08^{\dagger}$ & $0.83 \pm 0.04$ & $0.72 \pm 0.06$ & $0.94 \pm 0.04^{\S}$ & $0.96 \pm 0.01^{\|}$ \\
\hline $\mathrm{C}_{\mathrm{L}, \text { stat- } 4 \mathrm{~h}-h}, \mathrm{ml} / \mathrm{cmH}_{2} \mathrm{O}$ & $0.13 \pm 0.01$ & $0.11 \pm 0.01$ & $0.17 \pm 0.01$ & $0.16 \pm 0.01$ & $0.16 \pm 0.03$ & $0.36 \pm 0.01^{\dagger, \pm+\ldots, *^{* *}}$ \\
\hline \multirow[t]{2}{*}{ Infused } & \multicolumn{2}{|c|}{ Spontaneous breathing } & \multicolumn{4}{|c|}{ Mechanical ventilation } \\
\hline & $\mathrm{I}-\mathrm{C}_{4 \mathrm{~h}}$ & $\mathrm{I}-\mathrm{C}_{4 \mathrm{~h}-\mathrm{P}}$ & $\mathrm{I}-\mathrm{MV}_{\mathrm{L}}$ & $\mathrm{I}-\mathrm{MV}_{\mathrm{H}}$ & $\mathrm{I}-\mathrm{MV}_{\mathrm{L}-\mathrm{P}}$ & $\mathrm{I}-\mathrm{MV}_{\mathrm{H}-\mathrm{P}}$ \\
\hline $\mathrm{C}_{\mathrm{RS}, \mathrm{dyn}-0}, \mathrm{ml} / \mathrm{cmH}_{2} \mathrm{O}$ & & & $0.27 \pm 0.03$ & $0.35 \pm 0.04$ & $0.24 \pm 0.01$ & $0.22 \pm 0.02$ \\
\hline $\mathrm{C}_{\mathrm{RS}, \mathrm{dyn}-4 \mathrm{~h}}, \mathrm{ml} / \mathrm{cmH}_{2} \mathrm{O}$ & & & $0.19 \pm 0.02^{*}$ & $0.30 \pm 0.05$ & $0.24 \pm 0.01$ & $0.28 \pm 0.02^{*}$ \\
\hline $\mathrm{C}_{\mathrm{L}, \text { stat- } 4 \mathrm{~h}-\mathrm{l}}, \mathrm{ml} / \mathrm{cmH}_{2} \mathrm{O}$ & $0.84 \pm 0.04$ & $0.86 \pm 0.04$ & $0.89 \pm 0.07$ & $0.50 \pm 0.06^{\dagger}$ & $0.84 \pm 0.02$ & $0.91 \pm 0.02^{\|}$ \\
\hline $\mathrm{C}_{\mathrm{L}, \text { stat }-4 \mathrm{~h}-\mathrm{h}}, \mathrm{ml} / \mathrm{cmH}_{2} \mathrm{O}$ & $0.16 \pm 0.03$ & $0.16 \pm 0.01^{\ddagger}$ & $0.21 \pm 0.02$ & $0.12 \pm 0.02$ & $0.13 \pm 0.01 \diamond$ & $0.24 \pm 0.03^{\|, * *, \neq \ddagger}$ \\
\hline
\end{tabular}

${ }^{*}$ Different $(p<0.05)$ from $t=0$.

$\dagger$ Different $(p<0.05)$ from $C_{4 h}$.

$\ddagger$ Different $(p<0.05)$ from $C_{4 h-p}$.

$\S$ Different $(p<0.05)$ from $M V_{L}$.

II Different $(p<0.05)$ from not infused or infused $M V_{\mathrm{H}}$.

** Different $(p<0.05)$ from not infused or infused $M V_{L-P}$.

Different $(p<0.05)$ from I-MV $\mathrm{M}_{\mathrm{L}}$.

$\ddagger$ Different $(p<0.05)$ from I-MV $\mathrm{H}_{\mathrm{H}-\mathrm{P}}$.

\section{Table 3}

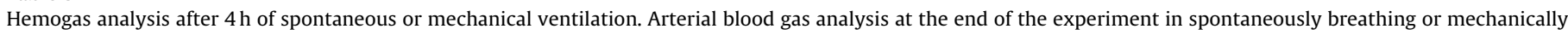

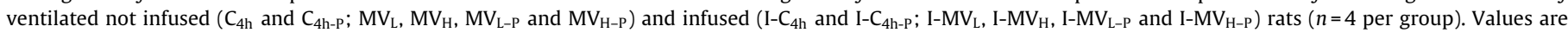
mean \pm SE. $\mathrm{pH}_{\mathrm{a}}$, arterial $\mathrm{pH} ; \mathrm{P}_{\mathrm{a}} \mathrm{CO}_{2}$, arterial $\mathrm{PCO}_{2} ; \mathrm{P}_{\mathrm{a}} \mathrm{O}_{2}$, arterial $\mathrm{PO}_{2} ; \mathrm{SBE}$, standard base excess.

\begin{tabular}{|c|c|c|c|c|c|c|}
\hline \multirow[t]{2}{*}{ Not infused } & \multicolumn{2}{|c|}{ Spontaneous breathing } & \multicolumn{4}{|c|}{ Mechanical ventilation } \\
\hline & $\mathrm{C}_{4 \mathrm{~h}}$ & $\mathrm{C}_{4 \mathrm{~h}-\mathrm{P}}$ & $\mathrm{MV}_{\mathrm{L}}$ & $\mathrm{MV}_{\mathrm{H}}$ & $\mathrm{MV}_{\mathrm{L}-\mathrm{P}}$ & $\mathrm{MV}_{\mathrm{H}-\mathrm{P}}$ \\
\hline $\mathrm{pH}_{\mathrm{a}}$ & $7.3 \pm 0.03$ & $7.3 \pm 0.03$ & $7.1 \pm 0.03^{*}$ & $7.3 \pm 0.01$ & $7.2 \pm 0.03^{*}$ & $7.2 \pm 0.04$ \\
\hline $\mathrm{P}_{\mathrm{a}} \mathrm{CO}_{2}, \mathrm{mmHg}$ & $54.9 \pm 2.7$ & $46.2 \pm 2.2$ & $81.4 \pm 7.5^{*}$ & $56.9 \pm 2.3$ & $76.3 \pm 7.1^{*}$ & $45.1 \pm 4.5$ \\
\hline $\mathrm{P}_{\mathrm{a}} \mathrm{O}_{2}, \mathrm{mmHg}$ & $83.7 \pm 1.5$ & $120.3 \pm 3.5^{\dagger}$ & $50.7 \pm 0.3^{*}$ & $75.3 \pm 3.9$ & $100.7 \pm 11.2^{\dagger \dagger}$ & $130.7 \pm 6.8^{*}$ \\
\hline $\mathrm{SBE}, \mathrm{mMl}^{-1}$ & $2.4 \pm 1.03$ & $-2.4 \pm 2$ & $-2.4 \pm 0.4^{*}$ & $-0.2 \pm 0.8$ & $0.8 \pm 1.9$ & $-7.2 \pm 1$ \\
\hline \multirow[t]{2}{*}{ Infused } & \multicolumn{2}{|c|}{ Spontaneous breathing } & \multicolumn{4}{|c|}{ Mechanical ventilation } \\
\hline & $\mathrm{I}-\mathrm{C}_{4 \mathrm{~h}}$ & $\mathrm{I}-\mathrm{C}_{4 \mathrm{~h}-\mathrm{P}}$ & $\mathrm{I}-\mathrm{MV}_{\mathrm{L}}$ & $\mathrm{I}-\mathrm{MV}_{\mathrm{H}}$ & $\mathrm{I}-\mathrm{MV}_{\mathrm{L}-\mathrm{P}}$ & $\mathrm{I}-\mathrm{MV}_{\mathrm{H}-\mathrm{P}}$ \\
\hline $\mathrm{pH}_{\mathrm{a}}$ & $7.3 \pm 0.01$ & $7.3 \pm 0.01$ & $7.0 \pm 0.02^{\dagger, \S}$ & $7.1 \pm 0.02^{*}, \S$ & $7.1 \pm 0.02^{*}, \S$ & $7.2 \pm 0.02$ \\
\hline $\mathrm{P}_{\mathrm{a}} \mathrm{CO}_{2}, \mathrm{mmHg}$ & $52.2 \pm 2.4$ & $52.9 \pm 2.8$ & $83.8 \pm 3.1^{*}$ & $63.8 \pm 6.0$ & $67.5 \pm 3.5^{*}$ & $53.9 \pm 3$ \\
\hline $\mathrm{P}_{\mathrm{a}} \mathrm{O}_{2}, \mathrm{mmHg}$ & $92.1 \pm 9.9$ & $90.0 \pm 4.2^{\ddagger}$ & $44.8 \pm 1.5^{*} . \S . \dagger \dagger$ & $81.1 \pm 3.2$ & $91.3 \pm 8.2$ & $142.6 \pm 8.5^{*}$ \\
\hline $\mathrm{SBE}, \mathrm{mMl}^{-1}$ & $-3.0 \pm 1.2^{\S}$ & $-3.1 \pm 0.86$ & $-6.9 \pm 2.2$ & $-6.9 \pm 0.6^{*}$ & $-5.4 \pm 0.9^{\S}$ & $-6 \pm 0.1$ \\
\hline
\end{tabular}

* Significantly different $(p<0.05)$ from $\mathrm{C}_{4 \mathrm{~h}}$.

$\dagger$ Significantly different $(p<0.001)$ from $C_{4 h}$.

i† Significantly different $(p<0.005)$ from $\mathrm{MV}_{\mathrm{L}}$.

$\S$ Significantly different $(p<0.05)$ from corresponding not infused.

$\ddagger$ Significantly different $(p<0.001)$ from corresponding not infused.

Table 4

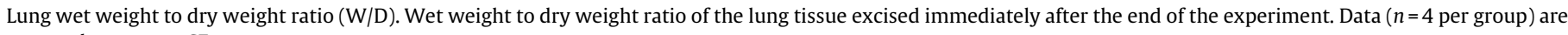
reported as mean $\pm S E$.

\begin{tabular}{|c|c|c|c|c|c|c|c|}
\hline & \multicolumn{3}{|c|}{ Spontaneous breathing } & \multicolumn{4}{|c|}{ Mechanical ventilation } \\
\hline & $\mathrm{C}_{0}$ & $\mathrm{C}_{4 \mathrm{~h}}$ & $\mathrm{C}_{4 h-\mathrm{P}}$ & $\mathrm{MV}_{\mathrm{L}}$ & $\mathrm{MV}_{\mathrm{H}}$ & $M V_{L-P}$ & $\mathrm{MV}_{\mathrm{H}-\mathrm{P}}$ \\
\hline Not infused & $4.9 \pm 0.1$ & $4.8 \pm 0.1$ & $4.7 \pm 0.1$ & $4.8 \pm 0.1$ & $4.8 \pm 0.04$ & $5.1 \pm 0.1$ & $5.4 \pm 0.1^{*,+, \downarrow, \S}$ \\
\hline Infused & & $5.0 \pm 0.2$ & $5.0 \pm 0.1^{\ddagger}$ & $5.2 \pm 0.1$ & $5.4 \pm 0.2^{* *}$ & $5.1 \pm 0.1$ & $6.1 \pm 0.3^{*,+,+,+\cdots \|^{* *}}$ \\
\hline
\end{tabular}

\footnotetext{
* Significantly different $(p<0.05)$ from $C_{0}$.

$\dagger$ Significantly different $(p<0.05)$ from $C_{4 h}$.

¥ Significantly different $(p<0.05)$ from $C_{4 h-P}$.

$\S$ Significantly different $(p<0.05)$ from $\mathrm{MV}_{\mathrm{L}}$ and $\mathrm{MV}_{\mathrm{H}}$.

I Significantly different $(p<0.05)$ from $\mathrm{MV}_{\mathrm{L}-\mathrm{P}}$.

** Significantly different $(p<0.05)$ in infused vs corresponding not-infused group.
} 


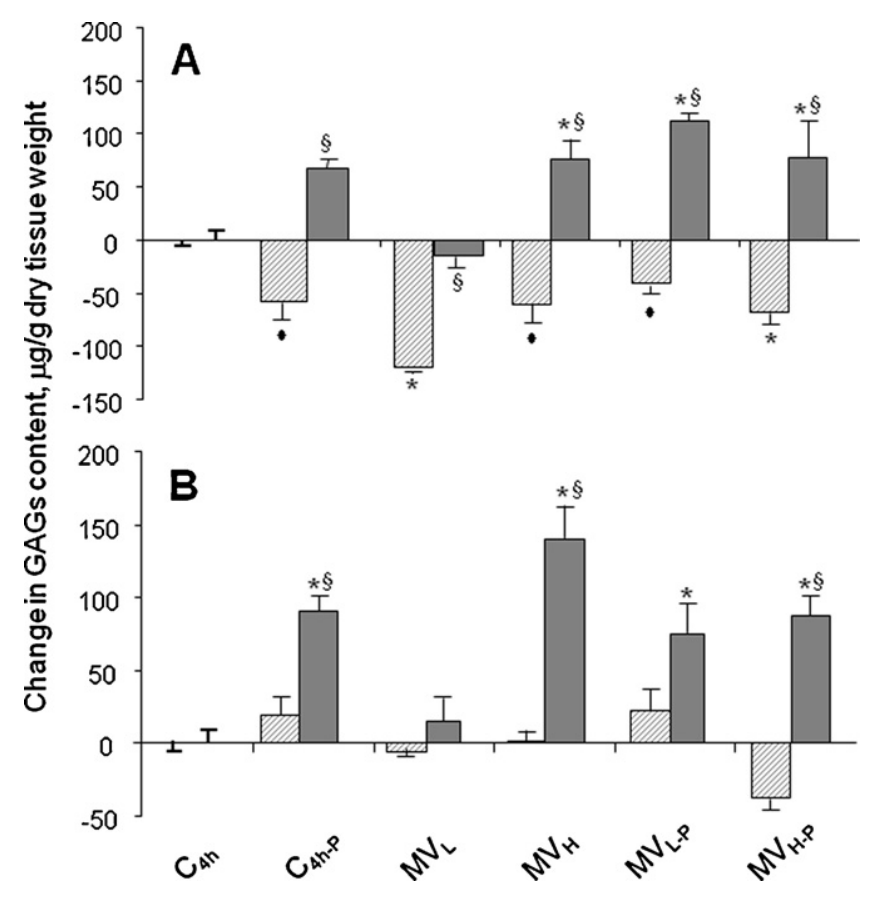

Fig. 3. Distinct behavior of pulmonary chondroitin sulfate-vs heparan sulfate-GAGs. Absolute differences $(\Delta)$ in chondroitin sulfate-GAGs (CS-GAGs; panel A) and heparan sulfate-GAGs (HS-GAGs, panel B) extraction with respect to $\mathrm{C}_{4 \mathrm{~h}}$ in not infused. $(\mathbb{Z})$ and PBS infused rat lungs $(\square)$ exposed to the different ventilatory strategies. Bars represent mean \pm SE. $N=4$ in each group. ( $\downarrow)$ Significantly different $(p<0.05$ ANOVA) from corresponding $C_{4 h}$. $\left(^{*}\right)$ Significantly different $(p<0.01$, ANOVA) from corresponding $C_{4 h}$. ( $\left.\S\right)$ Significantly different $(p<0.01$, ANOVA) from corresponding not-infused value.

in $\mathrm{MV}_{\mathrm{L}}$ and in $\mathrm{MV}_{\mathrm{H}-\mathrm{P}}$ lungs. Ventilation-dependent total GAGs extraction (Fig. 2A and B) closely reflected CS-GAGs extraction (Fig. 3A), while HS-GAGs (Fig. 3B) were unaffected by the ventilatory strategy. PBS infusion significantly increased total GAGs extraction (Fig. 2A) in all protocols except $\mathrm{I}_{-} \mathrm{C}_{4 \mathrm{~h}}$. In I-lungs, most of the extracted GAGs were HS-GAGs (Fig. 3B) with an only minor contribution of CS-GAGs (Fig. 3A).

The levels of active MMP-2 (Fig. 4A) and MMP-9 (Fig. 4B) were not significantly modified by the ventilatory strategies in NI-groups, although a significant increase of pro-MMP-9 was observed in $\mathrm{MV}_{\mathrm{H}}$ and $\mathrm{MV}_{\mathrm{H}-\mathrm{P}}$ with respect to $\mathrm{C}_{0}$. Saline infusion did not affect pro-MMP-2 and significantly decreased pro-MMP9, a phenomenon likely reflecting plasma dilution. Active MMP-2 significantly increased in $\mathrm{I}-\mathrm{C}_{4 \mathrm{~h}}, \mathrm{I}-\mathrm{C}_{4 \mathrm{~h}-\mathrm{P}}$ and $\mathrm{I}-\mathrm{MV}_{\mathrm{L}}$, but not in I$\mathrm{MV}_{\mathrm{H}}, \mathrm{I}-\mathrm{MV}_{\mathrm{L}-\mathrm{P}}$ and I-MV $\mathrm{H}-\mathrm{P}$ groups. Active MMP-9 was instead not affected by ventilatory strategy, but was significantly higher in I-MV $\mathrm{L}_{\mathrm{L}}$ I-MV $\mathrm{H}$, I-MV $\mathrm{L}-\mathrm{P}$ and I-MV $-\mathrm{MV}_{\mathrm{H}-}$ compared to corresponding notinfused groups.

In NI-lungs, TNF- $\alpha$ (Fig. 5A) and IL-1 $\beta$ (Fig. 5B) levels increased, with respect to $C_{4 h}$, in $C_{4 h-P}$ and in all mechanically ventilated groups. When comparing not infused and infused lungs, fluid load increased TNF- $\alpha$ amount only in ventilatory strategies implying a low $V_{\mathrm{T}}\left(\mathrm{C}_{4 \mathrm{~h}}, \mathrm{MV}_{\mathrm{L}}\right)$, while it did not modify IL-1 $\beta$ expression. With the exception of the NI-MV $\mathrm{V}_{\mathrm{L}-\mathrm{P}}$ group, where IL- 6 was significantly decreased with respect to corresponding $C_{4 h}$ values, IL-6 expression showed no specific modification with changing ventilatory strategy or tissue hydration (Fig. 5C).

\subsection{Morphology}

Histological sections of NI- and I-lungs are presented in Figs. 6 and 7, respectively. In NI lungs, the parenchyma was well preserved with no sign of injury. PBS infusion caused the patchy development of a mild perivascular cuff around lung microvasculature but no alveolar edema (Fig. 7). Inflammatory cells were not observed either in NI- (Fig. 6) or I-lungs (Fig. 7). From the Kolmogorov-Smirnov normality test, alveolar septa thickness and the area of tissue at alveolar confluence (alveolar corners) were not normally distributed and became normal (K-S Dist. values ranging from 0.054 to 0.142 and $p$ values ranging from 0.081 to $>0.20$ ) after being transformed into their natural logarithms. The antilogarithm

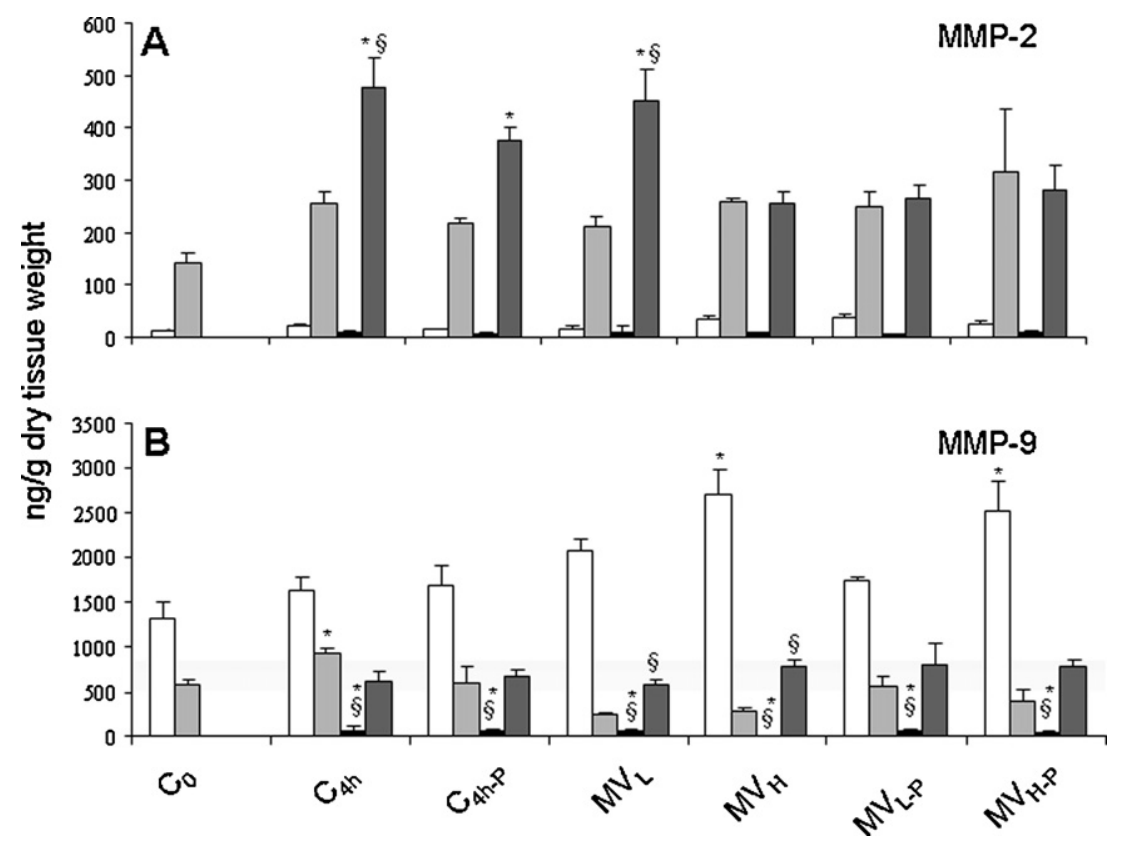

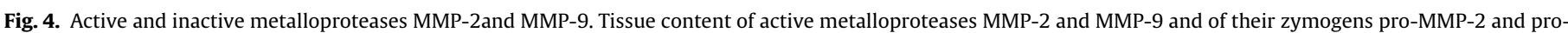

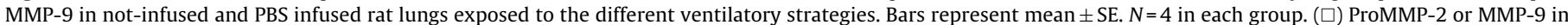

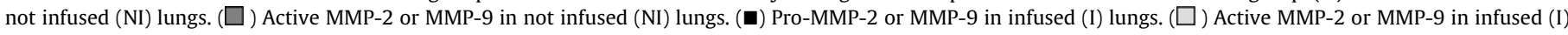
lungs. $\left(^{*}\right)$ Significantly different $\left(p<0.01\right.$, ANOVA) from corresponding $C_{4 h}$. ( $\left.\S\right)$ Significantly different $(p<0.01$ ANOVA) from corresponding not-infused value. 

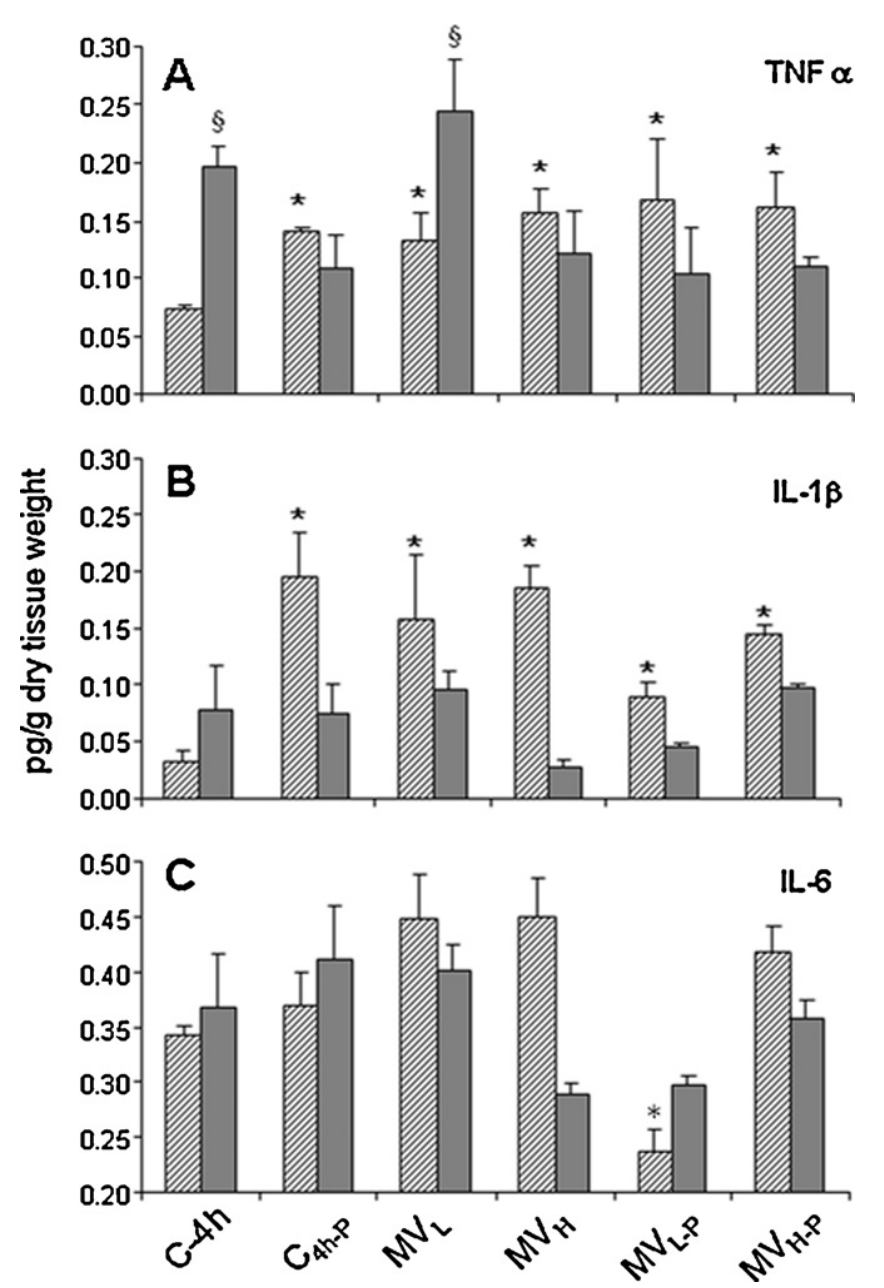

Fig. 5. Inflammatory markers. ELISA test representing the amount of interleukins rTNF- $\alpha$ (panel A), rIL-1 $\beta$ (panel B) and IL-6 (panel C) in lung tissue in not-infused ( $\square$ ) and infused $(\square)$ rats. $N=4$ per group. Bars represent mean \pm SE. $\left({ }^{*}\right)$ Significantly different $\left(p<0.01\right.$, ANOVA) from corresponding $C_{4 h}$. ( $\left.\S\right)$ Significantly different $(p<0.01$, ANOVA) from corresponding not-infused value.

of the mean of the log-normal distribution, i.e. the geometric mean of alveolar septa thickness and corner region area is presented in Fig. 8A and B, respectively. While the ventilatory strategy "per se" did not affect septa thickness (Figs. 6 and 8A), PBS infusion determined a significant $(p<0.05)$ thickening of the interalveolar septa (Figs. 7 and $8 \mathrm{~A}$ ) and, with the exception of $\mathrm{MV}_{\mathrm{H}-\mathrm{P}}$, a significant enlargement of corner region (Figs. 7 and 8B).

\section{Discussion}

In the present experimental study performed on healthy animals, we investigated the following hypothesis: (a) mechanical ventilation induces worse damage in pulmonary GAGs as compared to spontaneous breathing; (b) PEEP is protective on pulmonary GAGs during mechanical ventilation, independently of tidal volume; (c) the administration of fluids may further damage pulmonary GAGs in association with mechanical ventilation. Biochemical analysis of the lung specimen indicate that: (a) in the absence of fluid load, pulmonary GAGs recovery decreased in spontaneous ventilation with PEEP and in most of the mechanical ventilation regimens; (b) GAGs extraction increased when mechanical ventilation and/or PEEP was coupled to mild fluid load; (c) PEEP was protective toward lung parenchyma at low, but not at high $V_{\mathrm{T}}$; (d) up to $4 \mathrm{~h}$, GAGs degradation/remodeling did not reflect an inflammatory process but, rather, a direct damaging impact attributable to the stress/strain associated to positive pressure ventilation.

Mechanical ventilation was performed at either a low, physiological $V_{\mathrm{T}}$ or at the highest $V_{\mathrm{T}}$ with and without PEEP set at $5 \mathrm{cmH}_{2} \mathrm{O}$ compatible with $4 \mathrm{~h}$ animals survival; PEEP was set at $5 \mathrm{cmH}_{2} \mathrm{O}$, i.e. in the lower range used in most experimental rats studies (Caironi et al., 2012). A comment is due on the fact that, in order to guarantee that, for each ventilatory/fluid load protocol, the lungs employed for respiratory mechanics and biochemical analysis had been exposed to exactly the same procedure as those used for morphological analysis, all lung tissue specimen were collected after performing the static pressure-volume curves, a procedure which potentially alter lung tissue structure. However, since the same procedure was uniformly applied to all lungs, including $\mathrm{C}_{4 \mathrm{~h}}$ controls that did not show any sign of parenchymal lesion, we assume that the P-V maneuver was not responsible for the observed differences between protocols.

\subsection{Spontaneous and mechanical ventilation at two levels of tidal volume in normally hydrated lung}

The lower GAGs extraction in $C_{4 h-P}$ as well as in $M_{L}, M V_{H}$, $\mathrm{MV}_{\mathrm{H}-\mathrm{P}}$ and $\mathrm{C}_{4 \mathrm{~h}-\mathrm{P}}$ (Fig. $2 \mathrm{~A}$ and $\mathrm{B}$ ) suggests fragmentation and washout of GAGs from the lung matrix (Moriondo et al., 2007), the lower the extraction the higher the degree of GAG degradation. To better identify the interstitial structures where lung injury occur during different ventilation settings and simultaneous moderated fluid loading, the biochemical analysis was further refined by distinguishing, within total GAGs, the structural CS-GAGs in the matrix and the HS-GAGs in basal membranes. Pulmonary CSGAGs (Fig. 3A) seem particularly fragile when exposed to: (a) high $P_{\text {alv }}$ to re-expand collapsed peripheral airways and/or atelectasis (Tokics et al., 1987), as in $\mathrm{MV}_{\mathrm{L}}$, and/or (b) excessive $P_{\text {alv }}$ and/or $V_{\mathrm{T}}$ (Dreyfuss et al., 1988; Tremblay et al., 1997; Webb and Tierney, 1974), as in $\mathrm{MV}_{\mathrm{H}-\mathrm{P}}$. The observation that total GAGs reflected the CS-GAGs behavior (Fig. 2 and $3 A$ ) suggests that mechanical stress has a more profound impact on structural interstitial PGs then on HS-GAGs in endothelial and epithelia basement membranes, which were indeed significantly altered only with high $V_{\mathrm{T}}$ and PEEP (Fig. 3B). The greatest drop in GAGs extraction and the worst condition in terms of parenchyma integrity was observed in $\mathrm{MV}_{\mathrm{L}}$ lungs which, although ventilated at physiologically low $V_{\mathrm{T}}$ and the lowest $P_{\text {PEAK-AW }}$ (Table 1), developed the most severe hypercapnic and hypoxic acidosis (Table 3). Fragmentation of pulmonary PGs families might, at least partially, depend upon hypoxia $\left(\mathrm{F}_{\mathrm{I}} \mathrm{O}_{2}=0.12\right.$ ) (Miserocchi et al., 2001), increased $\mathrm{P}_{\mathrm{a}} \mathrm{CO}_{2}$ and decreased $\mathrm{pH}_{\mathrm{a}}$. Nevertheless, it is noteworthy that the acidic degradation of polysaccharides is described only in vitro in a not physiologic condition, whereas in vivo it was reported the role of synergistic damage to GAGs induced by $\mathrm{HOCl}$ and $\mathrm{O}^{*}-$ during inflammation (Rees et al., 2004). Fragmentation of a GAG as hyaluronan in lung during ischemia was recently discussed as a consequence of inflammatory process (Eldridge et al., 2011). A local marked acidosis induced by inflammatory cells may indeed induce direct GAGs cleavage in a specific microenvironment.

Compared to $\mathrm{MV}_{\mathrm{L}}$, the local tissue stress induced by mechanical ventilation at high $V_{\mathrm{T}}\left(\mathrm{MV}_{\mathrm{H}}\right)$ had a minor impact on alveolar and interstitial structures as suggested by the improved gas exchange (Table 3) and GAGs extraction (Fig. 2) without a direct involvement of the most common ubiquitous MMP-2 and MMP-9. Hence, our results suggest that in healthy lungs, mechanical ventilation with low $V_{\mathrm{T}}$ in the absence of PEEP induces fragmentation of GAGs, while ventilation with high $V_{\mathrm{T}}$ with no PEEP seems to minimize lung parenchyma damage. The observed greater GAGs degradation seems to be of mostly mechanical origin, i.e. related to increased 

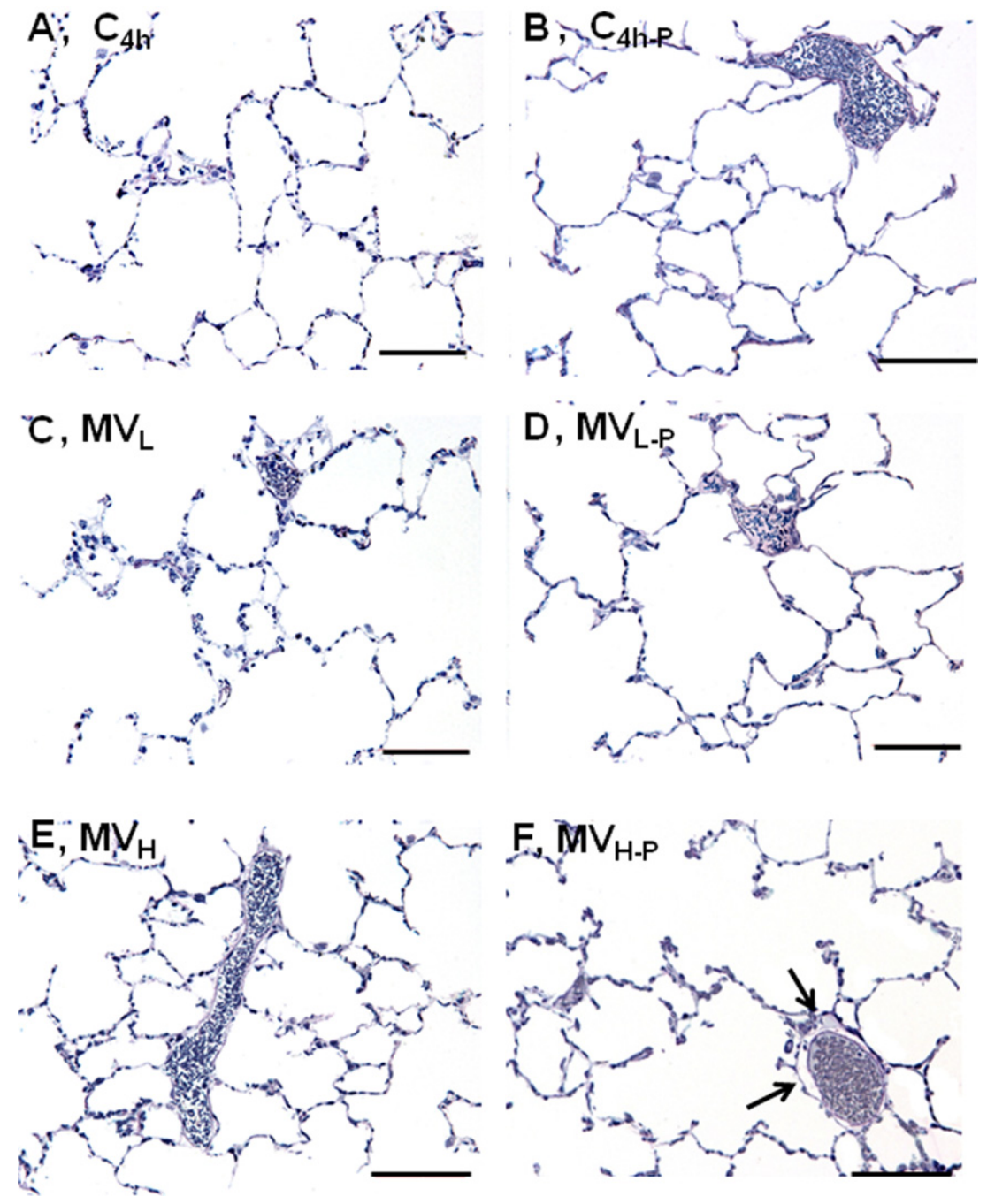

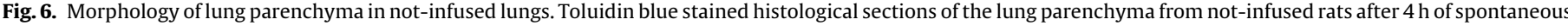
breathing $\left(C_{4 h}\right.$, panel A; $C_{4 h-P}$, panel B) or mechanical ventilation $\left(M_{L}\right.$, panel C; $M_{L-P}$, panel $D ; V_{H}$, panel $E ;$ and $M V_{H-P}$, panel F). Scale bars $=100 \mu m$.

tissue stress/strain, rather than a proteolytic phenomenon due to MMPs or other proteases activation.

\subsection{Effects of PEEP}

At low $V_{\mathrm{T}}\left(\mathrm{MV}_{\mathrm{L}-\mathrm{P}}\right)$, while restoring normal $\mathrm{P}_{\mathrm{a}} \mathrm{O}_{2}$, PEEP only mildly improved $\mathrm{PaCO}_{2}$ and acidosis (Table 3 ), and yet completely prevented fragmentation/washout of the GAG chains (Fig. 2A). This observation suggests that acidosis and/or hypercapnia play a secondary role in GAGs integrity. In contrast, at high $V_{\mathrm{T}}$, PEEP was injurious to the lung (Figs. 2 and 3 ) in spite of a recovered $\mathrm{P}_{\mathrm{a}} \mathrm{CO}_{2}$ (Table 3 ) and an increased lung compliance (Table 2 ). The decreased $V_{\mathrm{T}}$ observed in $\mathrm{C}_{4 \mathrm{~h}-\mathrm{P}}$ compared to $\mathrm{C}_{4 \mathrm{~h}}$ could be explained by both a reduction in lung compliance and respiratory drive induced by application of PEEP, which however was not observed in infused groups.

As previously observed (Moriondo et al., 2007), the lung W/D ratio (Table 4) was normal in all not-infused groups except $M V_{H-P}$, where excessive tensile stress was accompanied by a mild perivascular cuff, suggesting the development of interstitial edema (Fig. 6, panel F). Therefore, the present ventilatory protocols did not cause severe lesions such as those observed in patients in Acute Respiratory Distress Syndrome (ARDS) (Goodman et al., 1996; Meduri et al., 1995a,b; Suter et al., 1992). In fact we used healthy animals, while the severe lesions observed in patients with ARDS may be an association of the underlying disease and the inadequate ventilatory strategy. Our results suggest that PEEP could be particularly effective when combined with protective ventilation strategies with low tidal volume in healthy lungs as previously shown in ARDS mechanically ventilated patients (Briel et al., 2011; Brower et al., 2004).

\subsection{Mechanical ventilation and fluid load}

No data are available on the pulmonary impact of a judicious fluid load, recently proposed in perioperative settings and the intensive care (Kehlet and Bundgaard-Nielsen, 2009). We used crystalloids (PBS), the most widely used and recommended solution for intravascular volume replacement (Perel and Roberts, 2011), at a dosage commonly used during surgical intervention (Chappell et al., 2008). The macromolecular and mechanical changes occurring in the lung parenchyma at the onset of interstitial edema have been studied by our group through rabbit models of hydraulic edema induced by continuous saline infusion (Miserocchi et al., 1993; Negrini et al., 2006; Passi et al., 1998). These studies showed that, although plasma dilution increases the pressure gradient favoring capillary to interstitial fluid filtration, no interstitial edema develops if the fibrous interstitial scaffold is intact 

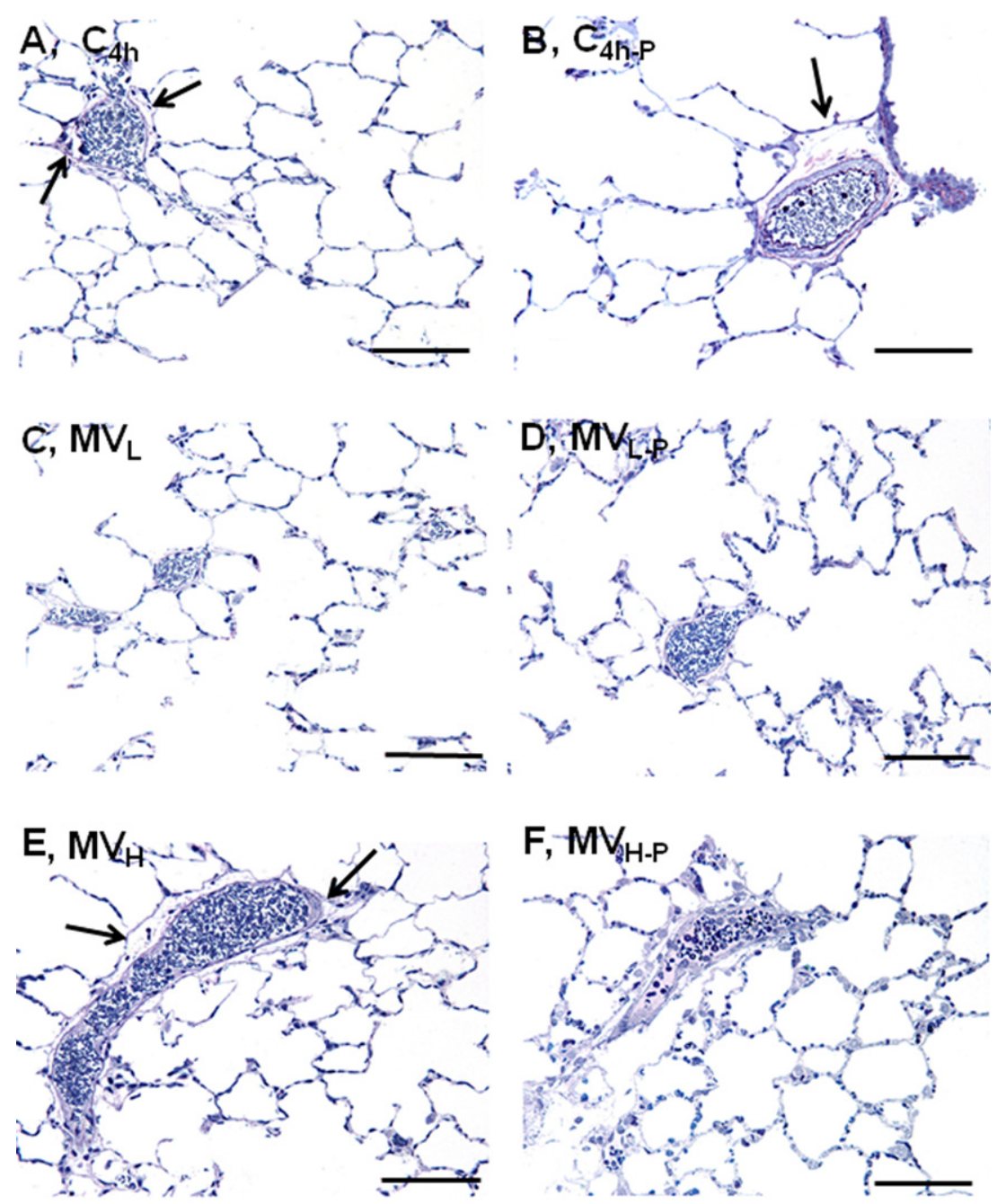

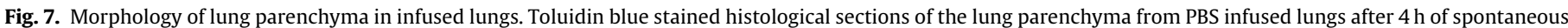

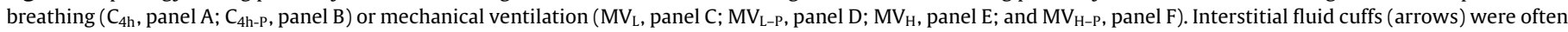
observed around lung microvasculature with no sign of alveolar edema. Scale bars $=100 \mu \mathrm{m}$.

and the mechanical compliance of the lung parenchyma is physiologically low. When bonds between PGs/GAGs and the other interstitial macromolecules are cleaved by activation of MMPs (Negrini et al., 2006; Passi et al., 1998) or excessive tissue stress (Moriondo et al., 2007), the mechanical compliance increases, allowing fluid accumulation and development of mild and eventually severe interstitial edema. Therefore, to allow a comparison of the biochemical results with the previous ones, in the present study we infused a colloid free solution, substituting saline with PBS to allow a better stabilization of $\mathrm{pH}$.

Assuming a normal value for rat of $13.5 \mathrm{ml}$ (Sharp and La Regina, 1998 ), plasma volume increased by $\sim 50 \%$ during infusion. The corresponding increase in $W / D$ ratio caused a significant thickening of alveolar corners (Fig. 7B), but not of alveolar septa (Fig. 7A); hence, in moderate interstitial edema, excess fluid is drained from alveolar septa toward alveolar corners (Bhattacharya et al., 1984, 1989) guaranteeing an efficient gas exchanges in the face of an increasing tissue fluid content. The increase of alveolar corner area not accompanied by an increased alveolar thickness is therefore a good index of the fact that, in spite of the observed GAGs fragmentation, our model focuses on the very early ventilatory-induced alterations of lung parenchyma. As previously reported (Negrini et al., 1996), PBS infusion caused in $\mathrm{I}-\mathrm{C}_{4 \mathrm{~h}}$ a mild, although not significant, increase of GAGs extraction in face of a normal W/D ratio. Mechanical ventilation further enhanced this phenomenon, all groups ventilated at positive $P_{\text {aw }}$ presenting a significantly increased GAGs extraction (Fig. 2) particularly when ventilated at high $V_{\mathrm{T}}$ with or without PEEP. A greater GAGs extraction may reflect: (a) easier mobilization, due to weakened hydrated intermolecular bonds, of resident otherwise not extractable GAGs. However, since our method allowed a complete extraction of GAGs from the tissue this source of GAGs ought to be, if any, negligible; (b) contamination of GAGs by hyaluronan. However, after testing with specific lyases (data not shown), this hypothesis was ruled out; (c) a circulatory pool of GAG fragments mobilized from highly vascularized tissues, such as kidney or liver. Indeed, the significant HS-GAGs extraction from NI-lungs suggests that fluid load, by increasing shear stress at the vessels wall (Adamson and Michel, 1993) may trigger remodeling of the endothelial basement membrane; (d) an increased deposition of newly formed GAGs in the lung tissue. In vitro studies (Breen, 2000; Xu et al., 1996, 1999) revealed the dependence of synthesis and turnover of interstitial tissue molecules upon local mechanical forces, suggesting an auto-regulatory response to strain-induced matrix breakdown. However, this hypothesis needs to be further investigated; indeed, while PG synthesis is very rapid in in vitro embryonic chick chondrocytes (half time, $\sim 90 \mathrm{~min}$ (Campbell and Schwartz, 1988; Mitchell and Hardingham, 1981)), it might be much slower in in situ lung fibroblasts. On the other hand, 

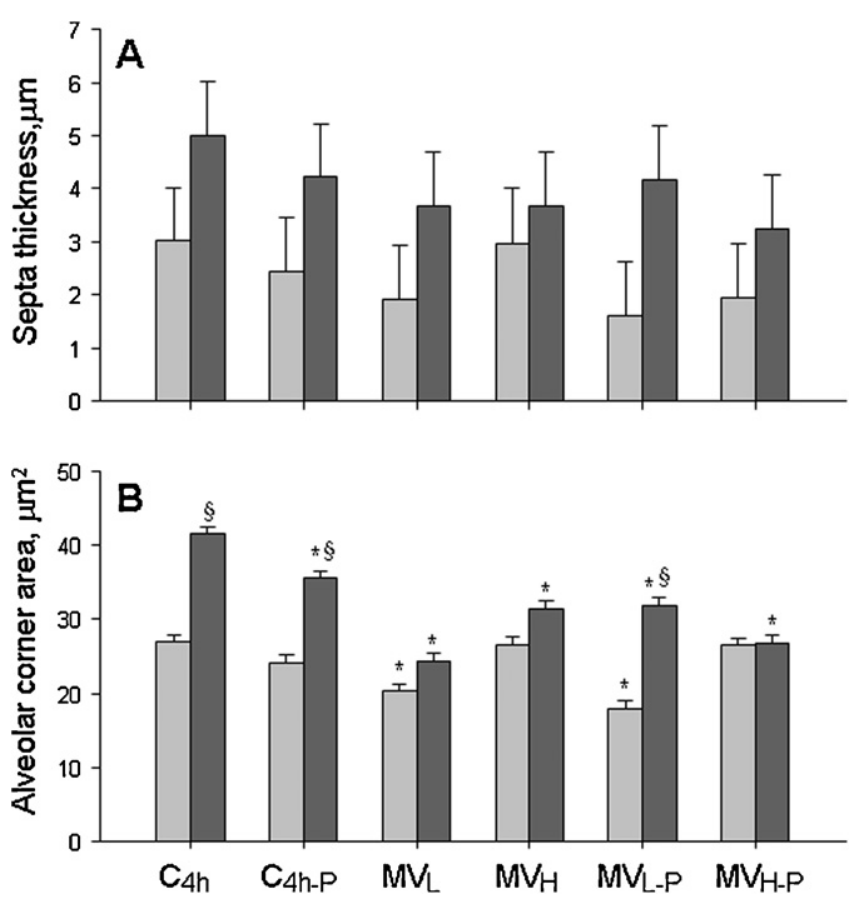

Fig. 8. Morphological evaluation. Thickness of the interalveolar septa (panel A, of interalveolar junction surrounding the extra-alveolar corner vessels (panel B) in lung samples from not-infused $(\square)$ and infused $(\square)$ rats. $N=4$ per group. Bars represent mean \pm SE. $\left(^{*}\right)$ Significantly different $\left(p<0.01\right.$, ANOVA) from corresponding $C_{4 \mathrm{~h}}$. ( $\left.\S\right)$ Significantly different $(p<0.01$, ANOVA) from corresponding not-infused value.

a significant increase of the protein component of CS-PG and HSPGs and a strengthening of the GAGs bonds has been reported after $2 \mathrm{~h}$ of mechanical ventilation at high $V_{\mathrm{T}}$ (Al Jamal and Ludwig, 2001). Hence, one cannot exclude the existence of a pool of tissue proteins available for fast PG synthesis when the tissue is challenged by diffuse interstitial edema. Therefore, a mild PBS infusion might trigger an early remodeling of the pulmonary matrix that might reveal protective to face the GAG degradation induced by high tissue stress inherent to mechanical ventilation. In a previous study performed in spontaneously breathing rabbits (Negrini et al., 1996), interstitial edema was attained through a much higher saline infusion rate $\left(0.5 \mathrm{ml} \mathrm{kg}^{-1} \mathrm{~min}^{-1}\right)$ than in the present study $\left(0.12 \mathrm{ml} \mathrm{kg}^{-1} \mathrm{~min}^{-1}\right)$. However, similarly to what observed in the present spontaneously breathing infused rats (Table 3 ), arterial $\mathrm{pH}_{\mathrm{a}}$ and $\mathrm{P}_{\mathrm{a}} \mathrm{CO}_{2}$ remained similar to control values during infusion with no sign of dilution acidosis. Instead, $\mathrm{pH}$ further decreased in infused and mechanically ventilated $\mathrm{I}-\mathrm{MV} \mathrm{V}_{\mathrm{L}}, \mathrm{I}-\mathrm{MV}_{\mathrm{H}}$ and $\mathrm{I}-\mathrm{MV}_{\mathrm{L}-\mathrm{P}}$ compared to corresponding NI rats (Table 3 ), suggesting that dilution acidosis might become relevant in previously suffering tissues.

It is worth noting that the spontaneous respiratory rate and airflow were significantly decreased with PEEP in NI- but not in I-rats. Potentially this could be due to the PEEP reducing the animal's respiratory drive, but the reduction in tidal volume did not occur in the infused group.

\subsection{Mechanical ventilation and lung mechanics}

A rather clear indication of the inadequacy of the PV curves as a reliable approach to detect early lung injury is provided by Fig. 1 and Table 4. In $\mathrm{MV}_{\mathrm{H}-\mathrm{P}}$ rats, application of PEEP increased $\mathrm{C}_{\mathrm{L}, \text { stat }}$, resembling pulmonary emphysema. However (Table 4), $\mathrm{C}_{\mathrm{L}, \mathrm{stat}}$ was not distinguishable from control in $\mathrm{I}-\mathrm{MV}_{\mathrm{H}-\mathrm{P}}$, one of the most lesional protocols in terms of GAGs extraction and W/D ratio. Therefore, at variance with previous observations (Sibilla et al., 2002), this study suggests that information from PV curves ought to be taken cautiously as they might prove unreliable to assess the extent of lung tissue damage.

\subsection{Inflammatory markers}

The concentration of TNF- $\alpha$, and IL- $1 \beta$ were elevated in all NI-lung groups compared to $\mathrm{C}_{4 \mathrm{~h}}$ (Fig. $5 \mathrm{~A}$ and $\mathrm{B}$ ), suggesting that positive pressure ventilation induces a mild non specific inflammatory response, no correlation emerging between TNF- $\alpha$ or IL- $1 \beta$ level, ventilatory strategy and GAGs degradation. Fluid load, implying insertion of an intravenous catheter and increased plasma volume, cardiac output and shear stress, also represented a proinflammatory insult, as indicated by the significant elevation of TNF- $\alpha$ in $\mathrm{I}_{-} \mathrm{C}_{4 \mathrm{~h}}$ compared to $\mathrm{C}_{4 \mathrm{~h}}$. However, TNF- $\alpha$ increased with respect to corresponding NI values, only in $\mathrm{I}-\mathrm{C}_{4 \mathrm{~h}}$ and $\mathrm{I}-\mathrm{MV}_{\mathrm{L}}$ lungs ventilated at low $V_{\mathrm{T}}$. TNF- $\alpha$ is synthesized by macrophages and other cell types including endothelial cells (Locksley et al., 2001); since no macrophage infiltration was detected in either NI- (Fig. 6) or I-lungs (Fig. 7), the increased TNF- $\alpha$ expression in $\mathrm{I}_{4} \mathrm{C}_{4 \mathrm{~h}}$ and I-MV $\mathrm{L}_{\mathrm{L}}$ might therefore reflect a greater inflammatory response of pulmonary endothelial cells exposed to limited parenchymal expansion, and likely increased vascular resistance, coupled to increased shear stress. Although IL-1 $\beta$ expression, which is instead released only by macrophages, tended to be lower in I- than in corresponding NI-lungs exposed to positive pressure ventilation, the differences did not attain a significance level, nor there was sign of a specific ventilatory strategy-induced IL-1 $\beta$ activation. A similar not specific and not significant variability was encountered in IL-6 expression when changing ventilatory pattern or plasma volume. Therefore, in line with previous observations (Bueno et al., 2002; D’Angelo et al., 2005; Moriondo et al., 2007), GAGs degradation did not directly depend upon the development of an inflammatory process. We cannot exclude the possibility that other inflammatory mediators can be activated in the longer term ventilation (Bregeon et al., 2002) and/or that GAGs breakdown fragments might provide an undetected pro-inflammatory activity. Thus, our data suggest that, in comparison with spontaneous breathing, mechanical ventilation "per se" acted as an activator of TNF- $\alpha$ and IL-1 $\beta$, but not of IL-6. The influence of mechanical ventilatory pattern in inducing the inflammatory response was minimized by infusion and interstitial edema suggesting that changes in the structure of GAGs and/or other matrix macromolecules may down regulate the local inflammatory response.

\subsection{Study limitations}

Although this study might provide useful hints on the potentially least invasive ventilatory setting to be employed in healthy humans, few limitations must be taken into accounts: (a) the experiments were performed in healthy animals and these results could be different in previously injured lungs; (b) we used a PEEP set at $5 \mathrm{cmH}_{2} \mathrm{O}$ a PEEP value used in experimental settings in ALI models in rats (Caironi et al., 2012); (c) although PBS infusion apparently mobilized HS-GAGs in the lung but also in non-pulmonary organs, likely the kidney, we did not verified peripheral organs damage; (d) few inflammatory markers were analyzed in the lung tissue, but not in blood and urine. Therefore, we cannot exclude the activation of other inflammatory mediators; (e) for ethical reasons, a limited number of animals were used. In case of lung morphology, even though we restricted the analysis to only two rats per group, we observed a relevant number of sections throughout all lung parenchyma. Therefore, we believe that these morphological data may enrich and complete the main functional data consisting in respiratory mechanics, arterial blood gases and biochemical analysis. In spite of these limitations, our study might still provide some 
useful indication for clinical ventilation of healthy lungs: (a) the use of low tidal volume should be always associated with the application of moderate PEEP levels, while high peak pressures should be avoided; (b) a judicious use of fluids must be always taken into account in the medical management.

\subsection{Conclusions}

In healthy lungs, positive pressure during spontaneous breathing and mechanical ventilation have a potentially injurious impact on the lung interstitial scaffold, and in particular on the CS-PGs structural component. Low tidal volume with PEEP minimized lung injury; Degradation/remodeling did not reflect an inflammatory process but, rather, the direct lesional impact to mechanical stress. Moderate fluid overload enhanced injurious effects of mechanical ventilation.

\section{Acknowledgements}

This research was funded by a Research Award of the European Society of Anesthesiology (ESA 2007) and by the University of Insubria Research funding (FAR 2009, 2010).

The Authors are deeply in debt with Dr. Barbara Bartolini for setting up the methods for the biochemical analysis, Dr. Eleonora Solari, for careful data analysis and to Prof. Daniela Quacci for her useful advices and constructive criticisms in the preparation of the manuscript. The authors gratefully acknowledge the "Centro Grandi Attrezzature per la Ricerca Biomedica" of Insubria University for instruments availability.

\section{References}

Adamson, R.H., Michel, C.C., 1993. Pathways through the intercellular clefts of frog mesenteric capillaries. J. Physiol. 466, 303-327.

Al Jamal, R., Ludwig, M., 2001. Changes in proteoglycans and lung tissue mechanics during excessive mechanical ventilation in rats. Am. J. Physiol. Lung Cell. Mol. Physiol. 28.

Baydur, A., Behrakis, P., Zin, W., Jaeger, M., Milich-Emili, J., 1982. A simple method for assessing the validity of the esophageal ballon technique. Am. Rev. Respir. Dis. $126,788-791$.

Bhattacharya, J., Gropper, M.A., Shepard, J.M., 1989. Lung expansion and the perialveolar interstitial pressure gradient. J. Appl. Physiol. 66, 2600-2605.

Bhattacharya, J., Gropper, M.A., Staub, N.C., 1984. Interstitial fluid pressure gradient measured by micropuncture in excised dog lung. J. Appl. Physiol. 56, 271-277.

Blumenkrantz, N., Asboe-Hansen, G., 1973. New methods for quantitative determination of uronic acid. Anal. Biochem. 54, 484-489.

Bradford, M., 1976. A rapid and sensitive method for the quantitation of microgram quantities of protein utilizing the principle of protein-dye binding. Anal. Biochem. 72, 248-254.

Breen, E.C., 2000. Mechanical strain increases type I collagen expression in pulmonary fibroblasts in vitro. J. Appl. Physiol. 88, 203-209.

Bregeon, F., Roch, A., Delpierre, S., Ghigo, E., Autillo-Touati, A., Kajikawa, O., Martin, T.R., Pugin, J., Portugal, H., Auffray, J.P., Jammes, Y., 2002. Conventional mechanical ventilation of healthy lungs induced pro-inflammatory cytokine gene transcription. Respir. Physiol. Neurobiol. 132, 191-203.

Briel, M., Meade, M., Mercat, A., Brower, R.G., Talmor, D., Walter, S.D., Slutsky, A.S., Pullenayegum, E., Zhou, Q., Cook, D., Brochard, L., Richard, J.C., Lamontagne, F., Bhatnagar, N., Stewart, T.E., Guyatt, G., 2011. Higher vs lower positive endexpiratory pressure in patients with acute lung injury and acute respiratory distress syndrome: systematic review and meta-analysis. JAMA 303, 865-873.

Brower, R.G., Lanken, P.N., MacIntyre, N., Matthay, M.A., Morris, A., Ancukiewicz, M., Schoenfeld, D., Thompson, B.T., 2004. Higher versus lower positive endexpiratory pressures in patients with the acute respiratory distress syndrome. N. Engl. J. Med. 351, 327-336.

Budinger, G., Sznajder, J., 2006. The alveolar-epithelial barrier: a target for potential therapy. Clin. Chest Med. 27, 655-669.

Bueno, P., Bueno, C., Santos, M., Oliveira Jr., I., Salomao, R., Pinheiro, B., Beppu, O., 2002. Ventilation with high tidal volume induces inflammatory lung injury. Braz. J. Med. Biol. Res. 35, 191-198.

Caironi, P., Langer, T., Carlesso, E., Protti, A., Gattinoni, L., 2012. Time to generate ventilator-induced lung injury among mammals with healthy lungs: a unifying hypothesis. Intensive Care Med. 37, 1913-1920.

Calabro, A., Benavides, M., Tammi, M., Hascall, V., Midura, R., 2000. Microanalysis of enzyme digests of hyaluronan and chondroitin/dermatan sulfate by fluorophore-assisted carbohydrate electrophoresis (FACE). Glycobiology 10, 273-281.
Campbell, S., Schwartz, N., 1988. Kinetics of intracellular processing of chondroitin sulphate proteoglycan core protein and other matrix components. J. Cell Biol. 106, 2191-2202.

Chappell, D., Jacob, M., Hofmann-Kiefer, K., Conzen, P., Rehm, M., 2008. A rational approach to perioperative fluid management. Anesthesiology 109, 723740.

D’Angelo, E., Pecchiari, M., Baraggia, M., Saetta, M., Balestro, E., Milich-Emili, J., 2002 Low-volume ventilation causes peripheral airway injury and increased airway resistance in normal rabbits. J. Appl. Physiol. 92, 949-956.

D’Angelo, E., Pecchiari, M., Della Valle, P., Koutsoukou, A., Milich-Emili, J., 2005. Effects of mechanical ventilation at low lung volume on respiratory mechanics and nitric oxide exhalation in normal rabbits. J. Appl. Physiol. 99, 433444.

D’Angelo, E., Pecchiari, M., Saetta, M., Balestro, E., Milich-Emili, J., 2004. Dependence of lung injury on inflation rate during low-volume ventilation in normal openchest rabbits. J. Appl. Physiol. 97, 260-268.

dos Santos, C., Slutsky, A., 2004. Protective ventilation of patients with acute respiratory distress syndrome. Crit. Care 8, 145-147.

Dreyfuss, D., Soler, P., Basset, G., Saumon, G., 1988. High inflation pressure pulmonary edema: respective effects of high airway pressure, high tidal volume and positive end-expiratory pressure. Am. Rev. Respir. Dis. 137, 1159-1154.

Duggan, M., Kavanagh, B., 2005. Pulmonary atelectasis: a pathogenic perioperative entity. Anesthesiology 102, 838-854.

Eldridge, L., Moldobaeva, A., Wagner, E.M., 2011. Increased hyaluronan fragmentation during pulmonary ischemia. Am. J. Physiol. Lung Cell. Mol. Physiol. 301, L782-L788.

Fehrenbach, H., Ochs, M., 1998. Studying lung ultrastructure. In: Uhligh, S., Taylor, A. (Eds.), Methods in Pulmonary Research. Birkhauser Verlag, Berlin, pp. 429-452.

Giancotti, F.G., Ruoslahti, E., 1999. Integrin signaling. Science 285, $1028-1032$.

Goodman, R.B., Strieter, R.M., Martin, D.P., Steinberg, K.P., Milberg, J.A., Maunder, R.J., Kunkel, S.L., Walz, A., Hudson, L.D., Martin, T.R., 1996. Inflammatory cytokines in patients with persistence of the acute respiratory distress syndrome. Am. J. Respir. Crit. Care Med. 154, 602-611.

Jain, M., Sznajder, J.I., 2007. Bench-to-bedside review: distal airways in acute respiratory distress syndrome. Crit. Care 11, 206.

Johnson, Z., Proudfoot, A., Handel, T., 2005. Interaction of chemokines and glycosaminoglycans: a new twist in the regulation of chemokine function with opportunities for therapeutic interventions. Cytokine Growth Factor Rev. 16, 625-636.

Karousou, E., Militsopoulou, M., Porta, G., De Luca, G., Hascall, V., Passi, A., 2004. Polyacrylamide gel electrophoresis of fluorophore-labeled hyaluronan and chondroitin sulfate disaccharides: application to the analysis in cells and tissues. Electrophoresis 17, 2919-2925.

Kehlet, H., Bundgaard-Nielsen, M., 2009. Goal-directed perioperative fluid management: why, when, and how? Anesthesiology 110, 453-455.

Locksley, R.M., Killeen, N., Lenardo, M.J., 2001. The TNF and TNF receptor superfamilies: integrating mammalian biology. Cell 104, 487-501.

Marini, J.J., Hotchkiss, J.R., Broccard, A.F., 2003. Bench-to-bedside review: microvascular and airspace linkage in ventilator-induced lung injury. Crit. Care 7, 435-444.

Mazzieri, R., Masiero, L., Zanetta, L., Monea, S., Onisto, M., Garbisa, S., Mignatti, P. 1997. Control of type IV collagenase activity by components of the urokinaseplasmin system: a regulatory mechanism with cell-bound reactants. EMBO J. 16, 2319-2332.

Meduri, G.U., Headley, S., Kohler, G., Stentz, F., Tolley, E., Umberger, R., Leeper, K., 1995a. Persistent elevation of inflammatory cytokines predicts a poor outcome in ARDS. Plasma IL-1 beta and IL-6 levels are consistent and efficient predictors of outcome over time. Chest 107, 1062-1073.

Meduri, G.U., Kohler, G., Headley, S., Tolley, E., Stentz, F., Postlethwaite, A., 1995b. Inflammatory cytokines in the BAL of patients with ARDS. Persistent elevation over time predicts poor outcome. Chest 108, 1303-1314.

Miserocchi, G., Negrini, D., Del Fabbro, M., Venturoli, D., 1993. Pulmonary interstitial pressure in intact in situ lung: the transition to interstitial edema. J. Appl. Physiol. 74, 1171-1177.

Miserocchi, G., Passi, A., Negrini, D., Del Fabbro, M., De Luca, G., 2001. Pulmonary interstitial pressure and tissue matrix structure in acute hypoxia. Am. J. Physiol. Lung Cell. Mol. Physiol. 280, L881-L887.

Mitchell, D., Hardingham, T., 1981. The effect of cycloheximide of the biosynthesis and secretion of proteoglycans by chondrocytes in culture. Biochem. J. 196, 521-529.

Moriondo, A., Pelosi, P., Passi, A., Viola, M., Marcozzi, C., Severgnini, P., Ottani, V., Quaranta, M., Negrini, D., 2007. Proteoglycan fragmentation and respiratory mechanics in mechanically ventilated healthy rats. J. Appl. Physiol. 103, 747-756.

Murphy, G., Nguyen, Q., Cockett, M.I., Atkinson, S.J., Allan, J.A., Knight, C.G., Willenbrock, F., Docherty, A.J., 1994. Assessment of the role of the fibronectin-like domain of gelatinase A by analysis of a deletion mutant. J. Biol. Chem. 269, 6632-6636.

Negrini, D., Passi, A., De Luca, G., Miserocchi, G., 1996. Pulmonary interstitial pressure and proteoglycans during development of pulmonary edema. Am. J. Physiol. Lung Cell. Mol. Physiol. 270, H2000-H2007.

Negrini, D., Tenstad, O., Passi, A., Wiig, H., 2006. Differential degradation of matrix proteoglycans and edema development in rabbit lung. Am. J. Physiol. Lung Cell. Mol. Physiol. 290, L470-L477. 
Parker, J.C., Breen, E.C., West, J.B., 1997. High vascular and airway pressures increase interstitial protein mRNA expression in isolated rat lungs. J. Appl. Physiol. 83, 1697-1705.

Passi, A., Negrini, D., Albertini, R., De Luca, G., Miserocchi, G., 1998. Involvement of lung interstitial proteoglycans in development of hydraulic and elastase induced edema. Am. J. Physiol. 275, L631-L635 (Lung Cell. Mol. Physiol. 19).

Perel, P., Roberts, I., 2011. Colloids versus crystalloids for fluid resuscitation in critically ill patients. Cochrane Database Syst. Rev., CD000567.

Rees, M.D., Hawkins, C.L., Davies, M.J., 2004. Hypochlorite and superoxide radicals can act synergistically to induce fragmentation of hyaluronan and chondroitin sulphates. Biochem. J. 381, 175-184.

Roberts, C., Wight, T., Hascall, V., 1997. Protoglycans. In: Crystal, R., West, J., Weibel, E. (Eds.), The Lung: Scientific Foundation. Lippincot-Raven, Phyladelphia, pp. 757-767.

Roughley, P., 2003. Proteoglycans in the lung. In: Garg, H., Roughley, P., Hales, C. (Eds.), Proteoglycans in Lung Disease. Marcel Dekker, New York, pp. $1-21$.

Sharp, E., La Regina, M., 1998. The Laboratory Rat. CRC Press, Boca Raton.

Sibilla, S., Tredici, S., Porro, A., Irace, M., Guglielmi, M., Nicolini, G., Tredici, G., Valenza, F., Gattinoni, L., 2002. Equal increases in respiratory system elastance reflect similar lung damage in experimental ventilator induced lung injury. Intensive Care Med. 28, 196-203.
Suter, P.M., Suter, S., Girardin, E., Roux-Lombard, P., Grau, G.E., Dayer, J.M., 1992. High bronchoalveolar levels of tumor necrosis factor and its inhibitors, interleukin-1, interferon, and elastase, in patients with adult respiratory distress syndrome after trauma, shock, or sepsis. Am. Rev. Respir. Dis. 145, 1016-1022.

Tokics, L., Hedenstierna, G., Strandberg, A., Brismar, B., Lundquist, H., 1987. Lung collapse and gas exchange during general anesthesia: effects of spontaneous breathing, muscle paralysis, and positive end-expiratory pressure. Anesthesiology $66,157-167$.

Tremblay, L., Valenza, F., Ribeiro, S., Li, J., Slutsky, A., 1997. Injurius ventilatory strategies increase cytokines and c-fos $\mathrm{m}$-RNA expression in an isolated rat lung model. J. Clin. Invest. 99, 944-952.

van den Hoogen, B.M., van Weeren, P.R., Lopes-Cardozo, M., van Golde, L.M., Barneveld, A., van de Lest, C.H., 1998. A microtiter plate assay for the determination of uronic acids. Anal. Biochem. 257, 107-111.

Webb, H.H., Tierney, D.F., 1974. Experimental pulmonary edema due to intermittent positive pressure ventilation with high inflation pressures. Protection by positive end-expiratory pressure. Am. Rev. Respir. Dis. 110, 556-565.

Xu, J., Liu, M., Liu, J., Caniggia, I., Post, M., 1996. Mechanical strain induces constitutive and regulated secretion of glycosaminoglycans and proteoglycans in fetal lung cells. J. Cell Sci. 109 (Pt 6), 1605-1613.

Xu, J., Liu, M., Post, M., 1999. Differential regulation of extracellular matrix molecules by mechanical strain of fetal lung cells. Am. J. Physiol. 276, L728-L735. 